\title{
RIVERA NAS MISSÕES ORIENTAIS
}

$-1828-$

Earle D. Macarthy Moreira

\section{I}

\section{"O FRUTINHO É MEU COMPADRE: É BOM DIABO, É MUITO VELHACO." (Marechal Sebastião Barreto)}

Transcorreu, sem maiores evocaçðes, o sesquicentenário do término da Guerra Cisplatina, conflito da maior importância para a vida das então embrionárias nacionalidades argentina, brasileira e uruguaia, sobre cujos destinos históricos exerceu influência das mais ponderáveis: aqui, abalando um trono e fazendo periclitar a integridade territorial do sul; ali, instituindo um estado soberano, aparentemente inviável; acolá, encaminhando o processo tirânico rosista e a conseqüente política del embudo, que iriam comandar, a médio prazo, o projeto nacional argentino.

No quadro daquele conflito, cujas origens remotas hão de ser perquiridas na história das disputas luso-espanholas pelo controle da Bacia Platina, avulta um personagem cujas contradições internas, se o tornam altamente controvertido até o presente, talvez por isso mesmo exercem sobre os estudiosos verdadeiro fascínio: Frutuoso Rivera $(1784$ ? - 1854).

Raramente um ser histórico se apresenta a cada interpelação, decorrido século e meio, com tamanha força de "estar". Espíritos apurados no trato da matéria histórica não têm conseguido sair indenes de seu convívio e a já alentada bibliografia que o refere peca, de ordinário, pela parcialidade emocional, embora os prefácios proclamem propósitos de isenção. Os ódios e os amores que ainda hoje desperta a memória daquele que se autodefinia como un oriental liso y llano, de per si desenham uma figura invulgar, definida magistralmente por um de seus biógrafos como "agonista por formación, antagonista por obligación y protagonista por vocación". ${ }^{1}$

A postura de Rivera frente à data de seu próprio nascimento é significativa: nunca deu maior importância ao factual. Em todos os seus escritos considera-se nascido em 1811 , no dia em que se juntou às hostes de Venâncio Benavídez. ${ }^{2} \mathrm{O}$ conceito vital imperou em seu relacionamento com o mundo: para todos os efeitos o sobrinho Bernabé, filho natural de sua irmã Maria Luísa, será seu "irmão" e não por mera caridade familiar. ${ }^{3}$

Gaúcho por excelência, só se sentia realmente a gosto entre a gente simples do campo, com a qual chegou a um grau de entrosamento notável. Nesse modo de ser, 
nenhum dos caudilhos orientais lhe chegou aos pés exceto, talvez, Aparício Saraiva: "llevaba el ambiente rural calado en los huesos". ${ }^{4}$ Suas qualidades de campeiro, jogador, vaqueano, mulherengo, matreiro e taura, afiançaram o seu prestígio não só na Banda Oriental como nas Províncias Unidas e mesmo no Rio Grande do Sul, abrigo certo nas horas amargas. Aqui, não era pequena nem de pouca valia a roda de seus "compadres" e "afilhados". Os rio-grandenses participaram da maior parte de suas correrias dando-lhe, com freqüência, o suporte humano e material de que carecia. Aliás, não há como contestar sua presença na vida política desta extremadura e a perturbação que dela advinha. $^{5}$

Rivera acompanhou Artigas até o final de sua gesta, destacando-se pela audácia e pela astúcia. As empresas que exigiam algo mais que a coragem ou a formação militar convencional the eram, invariavelmente, cometidas. ${ }^{6}$ As velhacadas, tão apreciadas nas rodas de galpão e que ganham vida na mitologia zoológica dos "causos" do graxaim, do tatu e do bugio, são o seu forte. Assim, deixará a pé o intrigante Manuel de Sarratea, emissário portenho encarregado de solapar a autoridade de Artigas, roubando-lhe a cavalhada. Anos mais tarde, repetirá o lance no episódio do Rincón de las Gallinas, que tanto doeu ao exército imperial. ${ }^{7}$

No ocaso artiguista, não foi dos primeiros a ceder. Enquanto, já em 1817, os Oribe e Rufino Bauzá desertam para Buenos Aires, Rivera mantém-se firme na causa até 1820, quando tudo há muito estava perdido. ${ }^{8}$ Em 2 de março daquele ano, rende-se em Tres Arboles a Bento Manuel Ribeiro, com quem irá contracenar pelo resto da vida. ${ }^{9}$ Esse episódio marca a sua adesão ao dominador luso-brasileiro e the tem valido a balda de traidor, o que é uma maneira distorcida de interpretar os fatos. Não pode ser desvinculado de outro do mesmo teor, ocorrido em 1825, quando é feito prisioneiro, em Monzón, por Lavalleja. Tudo indica que, num caso como noutro, muito mais havia além do acidente do destino. $^{10}$

A confusão em que deixava amigos e inimigos com peripécias dessa natureza, se bem examinadas as projeçб̄es históricas resultantes, refletem uma capacidade fora do comum para sobrelevar-se ao infortúnio e encaminhar fatores adversos à consecução de objetivos pessoais e políticos. ${ }^{11}$ Manipulador de circunstâncias por excelência, não encontrou capacidade equivalente nos campos adversários. Lecor parece ser o que esteve mais próximo de um contendor à altura e talvez o tivesse sido se a senilidade não the houvesse obliterado o discernimento e a capacidade de ação. Entre os próprios conterrâneos, nem Oribe nem Lavalleja, sequer nos momentos mais favoráveis, o puderam anular.

Desde o momento de sua adesão ao conquistador lusitano até ingressar na revolução dos Trinta e Três, foi Rivera alvo de toda a sorte de consideraçōes por parte de Lecor, galgando os postos militares até a categoria de Brigadeiro. Desempenhou o importante cargo de Chefe de Polícia da Campanha, o qual, virtualmente, lhe deu livre trânsito por toda a Banda Oriental e contribuiu de forma decisiva para alicerçar e difundir seu prestígio no meio da gauchada. Foi, pois, sob o manto protetor de Lecor, mas em proveito próprio, que Rivera assentou suas bases políticas na Campanha. Lá fundou povoados, instalou quartéis para os seus Dragões, agasalhou a gente pobre e firmou laços de compadrio com meio mundo. 
Essa co-participação na vida da Cisplatina, acatando a autoridade real e depois a imperial, foi tão intensa que permaneceu como marca indelével ao longo da existência, invocada e posta em evidência sob a luz mais desfavorável por seus inimigos, os quais não puzeram o mesmo empenho em relembrar as suas próprias posições naquela época. Quando compelidos a tanto, encontraram sempre boas razões para a autojustificação, negando-as, porém, a Rivera. Seu compadre Lavalleja, Manuel Oribe, Juan Francisco Giró e muitos outros, também apresentaram armas ao pavilhão dos Bragança. Talvez o fato de não haver embarcado no frustrado pronunciamento do Cabildo de Montevidéu, quando do conflito de lealdades entre Álvaro da Costa e Lecor, conseqüente da independência do Brasil, haja contribuído em muito para isso. Lavalleja, que havia seguido a onda, mal teve tempo de fugir para a outra banda e não haveria de esquecer, corresse o tempo que corresse, que enquanto penava em terra estranha o "compadre" prosperava e se fortalecia: ao grau de Cavaleiro da Ordem do Cruzeiro, em janeiro de 1823, seguia-se a promoção a Brigadeiro do Império, em maio, e a Comandância Geral da Campanha em $1824 .^{12}$

Aderindo à revolução oriental, em 1825, Rivera assegurou-lhe a oportunidade de sucesso no momento mais delicado. Praticamente, é ele quem define o futuro da nacionalidade uruguaia ao desamparar a causa do Império. Sua defecção, por tudo quanto ele representava em termos de poder e opinião na Campanha, tirou de Lecor qualquer possibilidade de conter a avalancha. Uma perspectiva duradoura para a Cisplatina como província imperial morreu aí, da mesma forma que também morria qualquer probabilidade de vida ordeira e progressista para o Estado Oriental, na medida em que se questionava a presença de Rivera na nova situação que se delineava.

A luta pelo poder, polarizada por Rivera, de uma parte, e por Lavalleja e Oribe, de outra, na medida em que se vai transformando num choque entre o meio rural e o meio urbano, entre a "barbárie e a civilização", segundo a concepção sarmentiana, impulsionará o Uruguai por uma senda de ferro e sangue que quase o leva à autodestruição. ${ }^{13}$

As dissidências internas são evidentes no próprio nascedouro da revolução e os sucessos das armas, longe de mitigá-las, incrementou-as a tal ponto que uma situação vitoriosa, paradoxalmente, levava ao comprometimento da causa. Isso, para desespero dos oportunistas portenhos que se haviam, depois de muita hesitação e corpo mole, decidido a correr os riscos da guerra.

Desde o momento de sua interferência declarada na contenda, o governo de Rivadávia tratou, sem deixar lugar a dúvidas, de eliminar os pruridos autonomistas da Banda Oriental, consoante suas diretrizes unitárias. A primeira e mais importante medida nesse sentido foi a integração das forças uruguaias no corpo do exército argentino. As divergências entre os vários caudilhos orientais de certa forma justificavam a medida como de coerência militar num estado de beligerância, mas a tradição artiguista, autonômica e federalista, não contribui para sua aceitação. A dispersão dos efetivos do Regimento de Dragões nas fileiras argentinas, determinada pelo General Martín Rodríguez, foi a medida que concorreu para o afastamento de Rivera do teatro de operações. ${ }^{15}$

O descompasso entre Lavalleja, Governador e Capitão-General da Província, e Martín Rodríguez, comandante das tropas argentinas, havia chegado, no primeiro semestre de 1826, a um extremo intolerável. Não havia acordo sequer na denominação dos exércitos: "Exército Oriental" para Lavalleja, "Exército Provincial" para Rodríguez. Logo 
surge o problema da autoridade, reeditando a situação ocorrida entre Artigas e Sarratea em 1812 .

Em 11 de março de 1826, Martín Rodríguez dirige-se a Lavalleja chamando-lhe, incisivamente, a atenção para a subordinação que lhe devia na direção da guerra contra o Brasil. A polemica daí resultante levou Rivadávia a pressionar a Junta de Representantes da Província Oriental, para que obrigasse Lavalleja a delegar o governo e a incorporar-se ao exército nacional. Nos primeiros dias de junho, o caudilho deu cumprimento a essa última determinação, mas com muitas reservas e morosidade, o que resultou na sublevação do Regimento de Dragões - muito ligado a Rivera - e sua incorporação ao exército argentino onde foi, de imediato, dissolvido e interpolado nos demais corpos.

Rivera, cujas desinteligências com Lavalleja iam num crescendo depois da batalha de Sarandi, ${ }^{16}$ resolvera, para escapar de seu comando, transferir-se para o "exército nacional", o que lhe foi concedido em janeiro de 1826. Nos últimos dias de fevereiro, nessa condição, achava-se em Daymán, com 400 homens, fazendo frente a Bento Manuel Ribeiro, cujas tropas se situavam na barra do Catalán. Embora as avançadas de ambos os chefes estivessem próximas, não se hostilizavam.

A dissolução do Regimento de Dragões desgostou profundamente a Rivera que, ato contínuo, requereu sua separação das fileiras e passaporte para Buenos Aires. Lá foi tratado com a maior consideração, enquanto que Martín Rodríguez era substituído no comando por Alvear.

O novo comandante-em-chefe, na ânsia de cortar pela raiz as dificuldades engendradas pela só existência de Rivera, tratou de destruí-lo material e moralmente. Neste último plano, foi armada monumental intriga cujo fito era incriminar o maldito pardejón $^{17}$ de entabular negociações secretas com os brasileiros.

Nunca é demais recordar que as peculiaridades da Guerra Cisplatina levavam a toda a sorte de negociações, na maior parte dos casos "por baixo do poncho", entre os chefes militares, que outra coisa não eram, salvo raríssimas exceções, senão caudilhos e caudilhetes com interesses econômicos os mais variados vinculados à região. Independentemente da origem castelhana ou portuguesa, eram com freqüência sócios e compadres. Rivera carteava com Sebastião Barreto e Bento Manuel Ribeiro. Bento Gonçalves fazia o mesmo com Lavalleja. O próprio General Martín Rodrígues entrou em tratos, por sua conta e risco, com Bento Manuel, insinuando a independência do Rio Grande do Sul. Desses passos todos há fartos vestígios nos arquivos de Buenos Aires e Montevidéu.

O fato é que Rivera foi acusado formalmente, tanto por Martín Rodríguez como por Alvear, de fomentar movimentos anárquicos entre os orientais visando entorpecer as ações bélicas e de manter correspondência criminosa com os imperiais. Devia, por isso, não só permanecer afastado do teatro das operações, como até encarceirado e processado. A uma intimação do governo argentino para apresentar-se a juízo (15-9-1826), ${ }^{18}$ segue-se violenta circular de Alvear noticiando sua fuga de Buenos Aires e ordenando sua prisão por qualquer pessoa que o encontrasse. Quem lhe desse auxílio seria considerado traidor da pátria. ${ }^{19}$

Ficava assim Rivera com a cabeça praticamente posta a prêmio e com todos os seus bens confiscados. Foi encontrar abrigo em Santa Fé, sob a proteção de Estanislau López. 
Para lá dirigem-se seus companheiros mais chegados e é lá que arquiteta o plano de invasão das Missðes rio-grandenses: operação cuja finalidade maior era "desmentir con hechos que asombren y llenen de horror" 20 seus inimigos e recuperar o crédito político na terra natal.

Está hoje cabalmente comprovado o estímulo dado por Dorrego, sucessor de Rivadávia, a esse projeto, embora as "memórias" de Manuel Alejandro Pueyrredón possan induzir em contrário. No jogo de espertezas em que se enredaram Dorrego e Rivera - a tradicional "pulseada" - oferecia o portenho ao oriental a oportunidade da redenção associada ao engodo de uma expedição sobre as Missð̋es, que só parasse nos limites do Rio Pardo, mas cujos fins últimos eram, na verdade, um posterior avanço contra o Paraguai e sua incorporação às Províncias Unidas. Assim Rivera era habilmente afastado do teatro principal da guerra, onde não o queriam presente nem Lavalleja nem Oribe. O elemento perturbador convertia-se, como por encanto, em agente dos interesses argentinos e seu talento militar e qualidades de liderança tomavam como alvo uma região rica e desprotegida do Império. Funcionaria a operação ou como mais um trunfo nas negociações de paz, já iniciadas, ou como abertura de uma nova frente capaz de dividir as forças brasileiras, cujos efetivos, lenta e dificultosamente arrebanhados, iam em todo o caso crescendo.

O suspicaz caudilho uruguaio simulou inteira concordância com o projeto global, usufruiu das vantagens decorrentes dessa atitude e manejou o assunto segundo suas próprias conveniências. A operação toda foi um verdadeiro passeio militar. Habilmente explorada por seus amigos e partidários converteu-se em feito napoleônico e seu condutor em genio de América! Dela resultou retornar ao Uruguai, aureolado pela fama, para reassumir a liderança política, que já não foi mais possível the arrebatarem de um todo. Amado e odiado com igual intensidade, morreu em rancho humilde a 13 de janeiro de 1854 , ao ser chamado de volta de um de seus exílios brasileiros.

\section{II}

\section{MANUEL ALEJANDRO PUEYRREDÓN (1792-1865)}

A Campanha das Missões de 1828, cujas implicações históricas estão a merecer estudos mais modernos, ${ }^{21}$ teve na figura do militar e escritor argentino Manuel Alejandro Pueyrredón o seu cronista principal. Membro de tradicional familia do patriciado portenho, fez quase toda a guerra da independência às ordens de San Martín, cuja amizade retribuía com verdadeira devoção. Sua patente de coronel ganhou-a nos campos de batalha: Maipu, Bio-Bio, Concepcion, Talcahuano, Curali.

Dotado de boa formação humanística, seus apontamentos e recordações, tomados às vezes no lombo do cavalo ou nos ócios forçados dos acampamentos, têm, além do sabor próprio de um estilo simples e direto, a inegável importância do depoimento registrado quase que no momento do acontecer.

Os Apuntes históricos relativos à invasão das Missð̌es Orientais por Rivera, cuja versão integral para o português estamos apresentando, têm sido de citação obrigatória para os historiadores interessados na Guerra Cisplatina e constituem, sem dúvida, o 
depoimento mais interessante e também mais desinteressado sobre o assunto. Os juízos que emite sobre os protagonistas são, via de regra, ponderados e sinceros.

Não deixa de ser com certo encantamento que, guiados pelos olhos inteligentes do árdego coronel, vamos seguindo os passos de sua aventura em terras brasileiras: a tormentosa entrevistas com Dorrego; o primeiro encontro com Urquiza, então mocito e fazendo sus pacotillas como mercachifle; as peripécias da viagem fluvial a que não faltou o ataque dos corsários; a primorosa descrição do velho e arruinado pueblo missioneiro de La Cruz; o ingresso em território do Império e a contemplação de um país risueño por su naturaleza; as ruínas e os imensos laranjais abandonados que produziam funda melancolia... Aliás, todo ele é simpatia para com os brasileiros que chegou a conhecer, estancieiros, soldados, embora deixe transparecer uma certa perplexidade quanto aos costumes e ao feitio das gentes: que modo curioso aquele de fazer a guerra do marechal Sebastião Barreto, que por nada deste mundo alterava a hora do almoço!

A descrição da região missioneira é um hino à ecologia: "Aquello es un verdadero panorama, cuya magestad anonada el espiritu ante el criador y sus obras estupendas!” Comovedor o espetáculo que retrata o êxodo dos indígenas, transplantados para a outra margem do rio Uruguai: à frente, os anciãos carregando os santos padroeiros; os músicos tangendo violinos; fechando a procissão, carretas carregadas com os objetos do culto e os sinos das igrejas. Atrás de tudo, a polvadeira levantada pelos cascos das dezenas de milhares de bois arreados por Rivera...

Na Biblioteca Nacional, ${ }^{22}$ em Montevidéu, Manuel Alejandro Pueyrredón tem as seguintes fichas:

- Escritos históricos..., notícia preliminar por Ramón Cárcano. Buenos Aires, Ed. J. Suárez, 1929, 360p.

- "Exposición que hace al público el coronel argentino D. Manuel Pueyrredón sobre las causas porque fué perseguido por el tirano de Buenos Aires. (Montevidéu, Imp. Oriental, 1838? ), 10p. - Carece de portada. Encadernado na Col. Melián Lafinur, vol. 38.

- "J.M.C. El husar desdichado: libro que contiene la memoria de Manuel A. Pueyrredón, poesía y canciones que tratan de la vida y la muerte de Don José Miguel Carrera." Santiago do Chile, Ed. Isla Negra, 1962, 95p.

- "Memoria sobre la Escuela Militar, dedicada al Gobierno Nacional." Buenos Aires, Imp. Bernheim y Bonco, 1861, 152p. Encadernado na Col. Melián Lafinur, vol. 62 .

- "Memorias inéditas del Coronel Manuel A. Pueyrredón. Historia de mi vida. Campaña del ejército de los Andes." Prólogo e notas de Alfredo G. Villegas. Buenos Aires, G. Kraft, 1947, 470p.

As "memórias" foram publicadas em vida do A., em folhetim, na Revista del Rio de la Plata.

O texto relativo à Campanha das Missóes foi reproduzido em 1911 no periódico montevideano Rivera. 


\title{
A CAMPANHA DAS MISSÕES DE 1828
}

\author{
Apontamentos históricos
}

I

Começarei estes fragmentos pelo que se refere à Campanha das Missões, durante a guerra com o Brasil, sob o comando do general D. Frutuoso Rivera, na parte em que fui ator.

Não é a história daquela campanha; tampouco é a do general Rivera: ambas as coisas pertencem a outra categor ia.

É uma cópia de meus apontamentos, que destinava para distração do lar nas veladas de inverno. Sem plano, sem ordem, sem método, como corresponde a simples lembranças consagradas à intimidade da família. Escritos, em suma, para não serem dados à luz pública.

Equivocar-se-ia muito quem buscasse neles a erudição, a literatura; a arte em nada foi levada em conta, nas minhas reminiscências.

Por isso o leitor encontrará coisas sem nome, aparentemente alheias ao assunto principal; mas, não deve ser esquecida a origem e o objeto.

Quanto ao protagonista, preciso é dizer que era um homem célebre sob todos os aspectos. Sua vida ocuparia volumes pelo papel que tem desempenhado no grande drama da revolução, pela qual tem seguido de conseqüência em conseqüência, por efeito natural da democracia e, devido à qual, sua figura respeitável pode ser considerada colossal.

Até aqui ninguém se ocupou em escrever a respeito desse personagem, cuja vida e façanhas, por si sós, bastam para caracterizar uma época.

A maior parte dos homens que o conheciam e que serviram às suas ordens, desapareceram sem deixar nada escrito. Depois deles, o que resta? A consciência póstuma não é o bastante. As gerações vindouras reclamam outra coisa; necessitam conhecer o passado para se inspirarem quanto ao futuro. Assim pois, a missão dos contemporâneos é fazer correr o véu que cobre os nossos caudilhos para lição dos que venham.

O general Rivera era um homem verdadeiramente célebre. Saído de uma classe vulgar, conservou até sua morte o exterior e as maneiras toscas do homem do campo; mas, possuía um grande talento natural, empregado sempre em intrigas e manejos para preencher suas aspirações e satisfazer sua insaciável sede de mando e de dinheiro. Assim, toda a sua política estava subordinada a estes dois objetos primordiais. $\mathrm{O}$ primeiro, para satisfazer sua vaidade que não conhecia limites; o segundo, para fazê-lo servir a seus fins e saciar sua inesgotável sensualidade. Tinha todas as qualidades do caudilho. Pródigo ao extremo, tudo dava. Com razão, se dizia dele que era um saco roto, pois nada the bastava. Pedia a quantos o rodeava, quase sempre para dar a outros, mas, não cobrava nem pagava. Era o homem dos grandes vícios, mas esses mesmos vícios tinham algo de heróico.

Durante a guerra civil, desempenhou um grande papel em seu país, onde era reputado a primeira capacidade militar e com efeito o era, mas puramente local. Muito prático do terreno, conhecia todos os montes, vales, rios, arro ios e picadas, até as menos freqüentadas. Isso the deu sempre uma grande vantagem sobre os seus inimigos. 
De todos os caudilhos da Banda Oriental, o general Rivera foi o mais manso e humano. Não era sanguinário, apesar de se ter formado na terrível escola de Artigas e servido com Otorgués, Blasito, Andresito, Encarnación, Casquito, Moreira, Gai e demais caudilhos de seu tempo, sendo ele o único que lhes sobreviveu.

De todos os comandantes de Artigas, Rivera foi sempre o que melhor se conduziu como militar e como homem de ordem; mas o que lhe deu mais reputação foi a conduta que observou em Montevidéu quando foi depor, por ordem de Artigas, o gaúcho Otorgués, primeiro governador imposto pelas montoneras, depois que as tropas de Buenos Aires, a mando do então coronel Soler, evacuaram aquela praça ( 27 de fevereiro de 1815).

Durante o governo de Otorgués, uma soldadesca desenfreada cometia todo o gênero de desordens, direi melhor, de crimes. Por esse motivo se fecharam as lojas e tabernas, as famílias viviam encerradas, ninguém tinha coragem de sair às ruas, sobretudo as mulheres, que eram ultrajadas em plena luz do dia.

Chegou a crescer pasto nas janelas, de estarem sempre fechadas.

O comandante Rivera depôs Otorgués que, em 2 de março daquele ano, expedira um pregão público impondo a pena capital aos que se atrevessem a criticar os atos de seu desgoverno; mandou sair toda a sua tropa de facínoras; restabeleceu a ordem e soube inspirar confiança aos moradores. Abriram-se de novo as casas de negócio; repôs o Cabildo; nomeou autoridades civis e começou, para esse desgraçado povo, uma era de reparação.

\section{Desde então D. Frutuoso Rivera foi o homem popular daquele país.}

Muitas ações deste gênero poderiam ser citadas, mas, como já disse, não é sua história a que vou escrever; simplesmente, pretendo referir alguns episódios da Campanha das Missões, os quais por sua qualidade não deixam de caracterizar o homem.

Em 1827, por efeito de desavenças com o general Lavalleja, se lhe mandou retirar para Buenos Aires, mas ainda ali o seguiu a animosidade de seus inimigos, que obtiveram do Governo, durante a presidência de Bernardino Rivadavia, uma ordem de prisão.

Rivera foi avisado e fugiu de Buenos Aires, indo asilar-se em Santa Fé, onde vivia tranqüilo sob o amparo do governador Estanislau Lopez.

D. Bernabé Rivera, sobrinho, mas a quem o general tratava de irmão, perseguido também na Banda Oriental, depois de ter andado algum tempo fugindo pelos montes com parte de um corpo de Dragões, não podendo sustentar a campanha, emigrou com vários chefes, oficiais e sessenta homens de tropa e foi reunir-se a seu irmão em Santa Fé.

Devido a isso, o general Rivera encontrou-se dono de uma força de aproximadamente 120 homens de todas as classes, mas carecia de meios para sustentá-los.

Em 20 de fevereiro de 1827, deu-se a batalha de Ituzaingó, que deixava desprotegida a província de Missōes.

O general Rivera projetou desde então a conquista dessa província; mas, como o governo de Buenos Aires lhe era adverso, adiou seu projeto para melhor tempo.

Em 27 de junho do mesmo ano, renunciou à presidência o Senhor Rivadavia e, no 12 de agosto imediato, foi nomeado governador, com a direção dos negócios gerais, o coronel D. Manuel Dorrego.

Essa troca de pessoas veio a favorecer o projeto de Rivera.

Nesse tempo, tendo que fazer uma visita a Santa Fé, por assunto particular, recebi de meu primo político D. Braulio Costa o encargo de visitar o general Rivera, agregando que se me ocupasse o servisse, que ele respond ia por tudo. 
Rivera me pediu dinheiro e, quando chegaram os Dragões, me pediu reses para a tropa; ambas as coisas the dei e, durante algum tempo, fui seu provedor sem receber nada.

Essa foi a origem de minhas relações com o mencionado general.

De volta a Buenos Aires, um dia encontrei-me com uma carta sua, na qual me convidava a tomar parte em sua expedição às Missōes.

Nessa carta, recordando que o havia servido, oferecia dar-me gados dos que se tomassem naquela Província.

Logo que tomei ciência de seu conteúdo, corri à casa do senhor D. Braulio a consultá-lo mas, sem dar-me resposta alguma disse:

- Deixe-me esta carta; amanhã the responderei.

No dia seguinte, eram 7 horas da manhã quando entrou em meu quarto.

- O senhor governador, me disse, deseja falar consigo.

- Que quer comigo o governador? contestei. Nå̉o tenho nada em comum com ele.

- Vamos apesar disto, replicou, e lá o veremos.

Resisti quanto pude a segui-lo, mas me comprometeu dizendo: prometi a ele e você não me há de fazer ficar mal. nância.

Eu queria muito a esse amigo e o segui ao Forte, ainda que com suma repug-

Não só não havia tido jamais relação alguma com o senhor Dorrego, como o considerava o inimigo jurado de minha família. privado.

No fundo da galeria que dava para o rio, encontrava-se Dorrego em seu gabinete

Estava de pé, diante de uma mesa onde havia um mapa estendido, e dava as costas para a porta.

Quando sentiu os passos, voltou-se. Estreitou a mão a D. Braulio, me fez apenas uma fria saudação com um movimento de cabeça e continuou em sua ocupação.

D. Braulio dirigiu-se a um sofá. Fiquei sem saber o que pensar daquela recepção.

Depois de uma ligeira pausa, voltou-se para onde eu estava e me disse:

- Mandei chamá-lo, senhor Pueyrredón, para ordenar-lhe que se apronte para seguir para as Missões, a fim de incorporar-se ao general Rivera, onde o encontrar.

Não há expressão com que ponderar a surpresa que me causaram essas palavras, unidas à recepção seca e desabrida que me havia sido feita.

Depois que me repus da primeira impressão, respondi: Fazer-me buscar para dar-me ordem, disse o senhor governador? A mim ninguém chamou. Esse senhor me disse simplesmente que V. Ex. ${ }^{a}$ queria falar comigo e não obstante de me ter recusado a vir, se o fiz foi por suas instâncias. Para dar-me ordem, insisti, para que siga para a campanha das Missões, diz V.Ex. ${ }^{\text {à }}$ A mim ninguém dá ordens e, por conseguinte, não vou.

Essa resposta produziu um diálogo muito animado.

- O senhor irá, voltou a dizer-me.

- Ó! não irei, retruquei. O governo tem muitos subalternos a quem mandar e a cujo número não pertenço.

- Quando a pátria necessita de seus filhos não há mais remédio que servi-la. 
- A pátria! a pátria! Bastante a servi; que a sirvam outros!

- Enfim, não há remédio, é preciso que o senhor vá.

- Sou um cidadão e não vou. em serviço. ${ }^{1}$

- O governo não reconhece a separação em que o senhor se apóia e o considera The disse:

Dirigindo-me então a D. Braulio, que não havia tomado parte alguma na disputa,

- Para isso me trouxe aqui, senhor D. Braulio?

Dorrego e eu estávamos parados, frente a frente como dois galos.

O senhor Costa levanta-se ruborizado e mete-se de permeio, dizendo:

- Mas senhor D. Manuel, isto não é o combinado: se o tivesse suspeitado, não teria trazido este senhor.

- Tem razão D. Braulio, retorquiu Dorrego, dando uma palmada na testa, e ajuntou: que quer o amigo, esta cabeça! esta cabeça! Veja o senhor - disse dirigindo-se a mim - esta cabeça é que é má, o meu coração é bom. O senhor D. Braulio me conhece. Perdoe-me, senhor Pueyrredón: venha comigo; e, tomando-me da mão, me conduziu a um sofá no qual me fez sentar, fazendo ele o mesmo a meu lado.

Falando-me com calma, disse e se expressou então, pouco mais ou menos, do seguinte modo:

- Vi sua carta. Não se fie das promessas de D. Frutos: é um homem que oferece muito e não cumpre nada. $O$ senhor não há de ser tratado melhor do que trata a todo o mundo.

Não tenho dúvida de que vai tomar as Missões e isso é o que mais sinto, porque nos vai causar muito mal.

Necessitamos a paz! a paz! Não podemos continuar a guerra! Rivadávia deixou o país como um esqueleto, exausto totalmente o tesouro. No Parque não há sequer uma bala para atirar à esquadra inimiga. Faço esforços inauditos para montar a fundição; não há um fuzil nem um grão de pólvora, nem com que comprá-la.

A nossa esquadra, que tanto serviço presta, está sem paga e sem provisões; o nosso estado não pode ser pior. Quando Rivadávia não pôde prosseguir, tinha razão, expressou a verdade. Pode-se fazer brotar recursos da terra, mas não é justo levar este povo ao extremo, esgotado também como o erário.

Eu sei que o Brasil também deseja a paz, mas a tomada das Missões vai causar-nos embaraço. Os brasileiros não as hão de querer ceder; D. Frutos não as vai entregar, porque as toma por sua conta.

O governo tratará de entender-se com ele; mas isso não basta, é preciso que todos os amigos desse homem vão, rodeiem-no e influam para que não embarace as negociações que o Governo se propõe entabolar. Nesse sentido, interesso-me em que o senhor vá; vou mandar chamar a D. Julian Espinosa, a D. Agustin Almeida e a quantos saiba que são amigos desse homem. $\vec{E}$ indispensável que o senhor parta; o país exige este novo serviço.

Sei - continuou - o motivo de sua oposição em servir. O posto, que com tanta injustiça lhe é escamoteado, dar-lho-á o governo, etc.

${ }^{1}$ No ano de 1826 eu servia na fronteira: havendo os índios invadido com três divisões fortes de 500 lanças cada uma, o regimento de Blandengues saiu a enfrentá-los; eu comandava a sua vanguarda $e$ com ela derrotei sucessivamente a todas as três em cinco ações e em três dias somente. O governo premiou aos que não se haviam batido e a mim nada, por cujo motivo renunciei e não queria servir mais. 
Minha resposta a tudo isso foi dizer-lhe:

- Agora sim nos entendemos, senhor governador. Está muito bem; partirei e farei quanto me for possível no sentido dos objetivos do governo, apesar de que não me posso lisonjear de poder influir nas determinações do general. Minha relação não alcança a tanto.

- Não importa - replicou - com um pouco de cada um farão um todo.

- Pois bem, partirei, mas como simples particular; quero estar com liberdade para voltar quando assim o entender.

- De nenhum modo - replicou Dorrego - aceite o emprego que o governo lhe oferece. Creia-me: como particular nada obterá de D. Frutos; pelo menos é preciso que tenha o seu soldo.

Ficamos combinados de que assim seria.

- Vou mandar pôr uma canhoneira à sua disposição, para que o leve ao Arroyo de la China: desse modo, o senhor economizará uma grande volta. Quanto ao mais, receberá minhas ordens dentro de dois dias.

Assim concluiu essa singular entrevista, na qual quase teve lugar uma rixa.

Entretanto - verdade seja dita - depois disso, o senhor Dorrego conduziu-se muito bem a meu respeito.

Foi mandado aprontar a canhoneira. O capitão do porto, coronel D. Francisco Linch, veio um dia dizer-me: - Tenho ordem de por à tua disposição uma canhoneira de guerra. Mandei aparelhá-la, mas necessita de certos reparos: terias que demorar-te alguns dias. Aproveitei essa demora para fazer uma viagem a Chascomús, onde me detive bastantes dias.

Mas antes disso, o coronel Linch perguntou se não me tinham ido procurar dois rapazes que solicitavam passagem para Entre-Rios. Respondi-lhe que não. - Pois hão de procurar-te, porque lhes informei que, estando a canhoneira à tua disposição, deviam avir-se contigo. Perguntei-lhe quem eram. - São dois mocinhos que vêm aqui, fazem as suas pacotilhas como mascates e aproveitam estas ocasiões para retornar. Dei-lhes passagem de outras vezes, ajuntou. - Pois sendo assim, dá-lhes também agora e economiza a visita. Melhor para mim, pois irei mais acompanhado.

Quão longe estava de pensar que um deles seria o futuro vencedor de Caseros, o que derrubou o tirano Rosas!

Em relação a essa viagem, houve outra circunstância que não devo passar em silêncio, pelo papel que desempenhou o homem no tempo das perseguiçōes que sofri de Rosas.

Linch me havia dito que estava escasso de oficiais porque todos se achavam embarcados, por estar a esquadra inimiga à frente.

- Mas tenho um contramestre de arsenal, excelente homem, que irá comandar a canhoneira. Melhor para ti, pois poderás mandá-lo à tua vontade.

- Tanto faz, foi minha resposta.

Esse contramestre era um português chamado José Ferreira; mais tarde, voltaremos a encontrar-nos com ele.

À minha volta de Chascomús, as coisas tinham mudado de aspecto e obrigado o governo a tomar outras medidas. 
O general Rivera havia voado e caído de improviso sobre a província das Missões, entrando pela fronteira Oriental. Bateu o coronel Alencastre na costa do Ibicuí, depois do que já não teve quem fizesse oposição à sua conquista.

O general Lavalleja, que mandava na Banda Oriental, destacou uma força volante sob o comando do coronel Manuel Oribe para persegui-lo no território Oriental; mas Oribe, excedendo suas instruções, penetrou no de Missões e, na mesma costa do Ibicuí, chocaram-se as vanguardas de ambas as forças e houve dois ou três mortos de cada parte. Como Rivera já havia engrossado a sua tropa, parte com orientais que se lhe haviam reunido, parte com correntinos, as forças permaneceram algum tempo sem operar: Oribe, esperando a ocasião de batê-lo ou esperando reforços; Rivera evitando todo o choque que piorasse a sua posição.

Por esse motivo, tratou de dar conta ao governo geral de ter tomado posse das Missões e se submetia, por conseguinte, ao governo de Buenos Aires. Este deu ordem, imediatamente, ao general D. Estanislau Lopez de marchar sobre as Missões, a fim de tomar a direção da guerra por aquela parte. Para tanto, sua divisão de santafecinos foi reforçada com 250 recrutas cordoveses e vários outros contingentes para formar um exército. Remeteu-se ordem, ao mesmo tempo, ao coronel Oribe para que se retirasse e fosse ocupar seu posto na linha de Montevidéu.

Dono da campanha, Rivera continuou as suas operações. Foi sucessivamente ocupando os povoados, ao mesmo tempo em que se engrossava a sua força, com a qual se havia situado em Itaqui, quando se apresentou o general Lopez com a sua divisão na parte ocidental do Uruguai e ali o encontrou.

O general Rivera recusou submeter-se a Lopez. Mandou oferecer-lhe auxílio de gados para a sua retirada, o que não foi aceito por Lopez e, durante alguns dias, trocaram notas que deram por resultado que este empreendesse a retirada, entregando a Rivera os contingentes que levava: com o que começou a formar-se o Exército do Norte sob a direção do coronel D. Manuel Escalada, nomeado chefe do Estado Maior Geral.

Devido a todas essas circunstâncias, minha viagem tinha sido postergada. Entretanto, resolveu-se reforçar o Exército do Norte com um esquadrão de artilharia às ordens do coronel D. Eduardo Trolé, que foi incorporado com mais de vinte oficiais. Entre estes recordo o capitão D. Martiniano Chilavert que, andando o tempo, morreu fuzilado por ordem daquele mesmo bufarinheiro que, como já disse, ia de passageiro na canhoneira com a sua pacotilha; o capitão D. José Maria Piran, atual general, e o tenente de infantaria D. Miguel Galan, que chegou a general e a ministro da Guerra no Paraná. Dos demais somente tenho presente que havia entre eles vários franceses. No que me dizia respeito, levava instruções em separado.

A viagem foi longa por causa de maus tempos, varações e, mais que tudo, porque só navegávamos de dia, por temor de uns corsários que andavam pelo Uruguai, os quais fizeram uma ameaça sobre a canhoneira numa manhã, mas retiraram-se sem atacá-la.

Durante a viagem não tive contacto algum com a comitiva, porque todos iam alojados no porão: na câmara íamos Trolé e eu. Como durante toda a navegação passavam jogando e eu não era dado a essa diversão, jamais me acerquei deles. Essa foi a causa de não conhecer o depois vencedor de Caseros.

No Arroyo de la China demoramos também muitos dias para comprar cavalhada para a marcha e para levar ao exército. Por esse motivo e por seu eu o encarregado da referida operação, me apossei de uma magnífica tropilha, que daí por diante me serviu muito.

Por fim, marchamos para Missões pela costa ocidental de Curuzú-Cuatiá, que foi o último lugar habitado por aquela parte: dali para diante, tudo era deserto.

Na marcha, visitamos as ruínas do antigo povoado de Yapeyú, pátria do general San Martin. La Cruz era o que, por então, havia resistido mais à ação destruidora dos 
tempos. As maciças paredes de sua igreja conservavam-se intactas. Um grande pátio cercado de corredores, contidos por colunas de pedra sobre pedestais do mesmo material, permanecia todavia em bom estado.

No centro desse pátio se via um quadrante que muito nos chamou a atenção. Em um formoso pedestal de pedra perfeitamente lavrado, erguia-se uma coluna de 5 varas, de uma só peça. Sobre essa, descansava a pedra quadrada em que marcava o gnômon ou estilo, colocado de modo que se pudesse ver por ambas as partes. Sua posição era perpendicular, mas com uma pequena inclinação ao meridiano. As pinturas que adornavam essa coluna, oitavada em faixas verticais de quatro dedos de largura, apagadas pelo pó, apareciam descoloridas; mas, quando lavamos alguns pedaços, se viu a pintura amarela e verde tão viva como se acabasse de ser posta, apesar de fazer oitenta anos segundo a data esculpida na própria pedra.

O cemitério era um quadrilongo cercado com renques de árvores. Todos os sepulcros tinham lápides de diferentes cores, com inscrições em guarani a maior parte delas. Havia algumas em espanhol e outras em latim. Viam-se também algumas molduras de formas raras e caprichosas.

Nessa linha os missioneiros estavam mais adiantados do que nós. Quando ainda se enterrava os mortos nas igrejas, já eles tinham campos-santos e usavam lápides e monumentos, o que não sucedia entre nós, homens civilizados, que olhávamos com desprezo os índios.

Em todo o trânsito de Curuzú-Cuatiá até Itaqui, não vimos mais habitantes que uns índios alçados que andavam boleando baguais, de que estavam cobertos aqueles campos. Ao avistar-nos fugiram, abandonando os animais manietados.

$\mathrm{O}$ aspecto do país era risonho por sua natureza. Coberto de árvores, cortado por rios e arroios cristalinos; mas não se podia prescind ir de um sentimento de melancolia ao cruzar uns lugares tão belos, tropeçando a cada passo com ruínas e vestígios de antigas propriedades, ostentando todas magníficos laranjais inteiramente abandonados.

Em Itaqui, incorporamo-nos à força que se organizava para formar um exército sob a direção do Coronel Escalada, que trabalhava ativamente e com a inteligência que é característica a esse distinto oficial.

O general Rivera recebeu-me bastante bem, mas com ar de mando, o que ocasionou que me fosse alojar com o coronel Escalada (D. Manuel).

geral.

A oito léguas de Itaqui, na costa do arroio de Itu, se estabeleceu o acampamento

Uma noite, estando nesse lugar, foi chamado o senhor Escalada pelo general-emchefe. Vendo que tardava, fiquei dormindo. Às 12 da noite, voltou e despertou-me para conversar.

- O senhor não é capaz - me disse - de adivinhar com quem acabo de estar?

- Certamente que não, respondi. Não tenho o talento da predição.

- Com o célebre Pancho Alzaga, replicou.

Veio esse tipo ver o general Rivera que, não querendo falar com ele, o mandou a Escalada. Solicitava entrar de serviço no exército. Escalada disse-lhe que isso não podia ser, que aquele exército estava já às ordens do governo de Buenos Aires, que o reclamaria.

Alzaga sustentava que era inocente, que o haviam caluniado e insistiu de tal modo em ser admitido que Escalada se viu na necessidade de contestar: - Senhor Alzaga, é preciso que saiba que seus cúmplices já não existem.

Alzaga se abateu. Ele não o sabia. Cobriu o rosto com ambas as mãos e confessou tudo: - $\hat{E}$ certo, senhor, sou um criminoso. 
O senhor Escalada tirou então 18 onças de ouro que lhe mandava o general Rivera e o despediu, dizendo-lhe: - Tome isto; vá-se embora senhor; fuja dos homens ou se faça digno deles.

A nossa conversa sobre esse homem tão horrivelmente criminoso e cuja causa estava já no conhecimento de todo o exército, durou até perto de clarear o dia.

Permanecemos uma longa temporada naquele acampamento, criando e disciplinando os corpos ao mesmo tempo em que se iam ocupando os povoados, sem perigos de nenhum gênero.

Desde que o coronel Alencastre abandonou a província depois de sua derrota de Ibicuí, nenhuma resistência se opôs à sua ocupação. Assim, aquela campanha foi de puras manobras, para o que o general Rivera era sumamente hábil.

Quando teve aviso de estar celebrada a paz de 27 de agosto de 1828 foi que desdobrou toda a sua atividade. Imediatamente despachou comissionados aos Sete Povos, que colocou sob tributação.

O plano que desenvolveu e levou a efeito foi formulado em virtude do tratado de paz, segundo o qual a província das Missões devia ser restituída ao Brasil.

Sua primeira idéia foi não dar cumprimento a esse capítulo do tratado, mas não encontrou apoio algum no exército e decidiu dirigir-se à Banda Oriental.

Tão logo soube que haviam nomeado governador do Estado o general D. José Rondeau, a 10 de dezembro desse mesmo ano, oficiou à Banda Oriental, de seu acampamento de Itu, pondo à disposição do novo governo o comando do exército.

O capitão D. Bernabé Magariños partiu para os povos a fim de trazèr tudo o que neles havia. Vários comissionados foram reunir os índios das reduções, com a finalidade de incorporar os homens ao exército e levar as famílias. Outro comissionado foi entender-se com os Charruas: índios nômades que ocupavam os desertos que mediavam, então, entre o Brasil e a Banda Oriental.

Seu objetivo era apresentar-se em seu país com forças consideráveis para impor e riquezas para deslumbrar.

\section{III}

Sem tardança, o exército se pôs em movimento, fracionado em dois corpos ou divisões, uma das quais, às ordens do coronel de dragões D. Bernabé Rivera, marchou em direção à costa do Ibicuí, onde devia esperar a reunião geral. Essa divisão se compunha de três armas.

A outra, às ordens do próprio general-em-chefe, dirigiu-se ao interior, em direção ou rumo do Rio Pardo. Só chegou até a aldeia da Picada de São Vicente, onde o governo imperial tinha grandes propriedades e estâncias, com numerosos rebanhos.

Algumas jornadas havíamos andado quando, um dia, passamos por um formosíssimo vale, à vista de uma estância, distante como meia légua, sobre uma cerrilhada.

Acabavam de chegar de Buenos Aires e outros pontos vários sujeitos, atraídos pelo aliciente dos rebanhos, dentre os quais recordo D. Mariano Gainza, D. Mariano Escalada, Mr. Raquin, D. Blas Despui, D. Pedro Espino, etc.

Todos esses senhores conversavam com o general. Estava também seu secretário D. Lucas Obes e eu, que desde que chegara havia sido nomeado seu ajudante-de-campo, quando vimos descer dos cerros e dirigir-se ao nosso acampamento dois ginetes em trajes de homens de classe. 
Logo que se acercaram todos, reconhecemos em um deles Pancho Alzaga: o outro era o dono da estância que vinha convidar o general a comer em sua casa.

À vista do primeiro, assim como uma bandada de pombas voa ao ver um gavião, assim toda aquela reunião se desfez deixando só o general com suas visitas.

A comitiva reuniu-se comigo a poucas varas dali e a conversação girou, como era natural, sobre a morte de D. Francisco Alvarez e a execução de Marcet e Arriaga, que todos os circunstantes haviam presenciado.

O general Rivera, provavelmente por causa do acompanhante, se escusou de aceitar o convite com pretexto de ocupações que não tinha e, levantando a voz, disse ao Doutor Obes que fosse em seu lugar com todos aqueles senhores - "e você amigo Luís, agregou, ficará comigo. Logo iremos de passagem tomar algo". Assim se fez, partindo a comitiva.

Pela tarde moveu-se a coluna e, ao passar pela estância, o general e eu nos dirigimos às casas.

Toda a comitiva saiu a recebê-lo. O Doutor Obes me explicou que, depois de comer, o dono da casa o levara a um quarto para que dormisse a sesta: você sabe - me disse - que eu não posso passar sem ela e aceitei. No fundo da peça, que era longa e estreita, havia duas camas, uma delas ocupada. Quis inteirar-me de quem era o meu companheiro de quarto e, quando reconheci a Francisco Alzaga, recusei descansar.

- É coisa singular, observei-lhe, que você tenha tido medo de dormir em um mesmo quarto com quem viveu e viajou muitos dias, quando o levou a Santa Fé escondido.

- É verdade, me disse: mas então não o acreditava um facínora; considerava-o inocente.

Entretanto, a divisão continuava a sua marcha e, à medida que avançávamos para o interior, o país se apresentava mais variado e formoso.

Em geral, os campos das Missões são quebrados, cobertos de cerros, arvoredos que se vão às nuvens, rios e arroios cristalinos, cujas margens oferecem ao viajante um paradouro agradável pelo luxo da vegetação e o contínuo cantar dos pássaros, abundantíssimos naquela região, a quem se agregam os banhos tão necessários em um país caloroso.

Além das serranias que se denominam gerais, encontra-se por todas as partes cerros isolados, que chamam de morros, cobertos de árvores seculares. O cedro, o pinheiro, o lapacho, o urunday, a murta e o amarelo são encontrados em grande e extraordinária abundância. Há também muitas frutas silvestres. O guabiju semelhante à ginja, o imbajaí, espécie de maracotão, o pêssego silvestre, goiabeiras, maracujá e mil outras de delicioso sabor.

Em meio das planícies, há multidão de bosques, pequenos e redondos, que chamam de capões, os quais são de um efeito surpreendente. Tudo ali é belo; que grande é a natureza, nesses apartados lugares! O homem se extasia contemplando as suas maravilhas e a riqueza de sua vegetação. Aquilo é um verdadeiro panorama, cuja majestade humilha o espírito ante o Criador e suas obras estupendas!

Os povoados das Missões são como todos os do Brasil, com casas de telha, de uma arquitetura especial e comum ao país. Quem viu uma casa, viu todas; mas, na campanha, encontram-se magníficos edifícios de dois e três andares, verdadeiros palácios, com todas as comodidades da vida: $\infty \mathrm{m}$ jardins e hortas de toda a classe de frutas e grandes laranjais.

Seus donos reúnem nelas quanto é necessário. Suas despensas estão abastecidas de tudo o que é preciso e até do supérfluo. 
Os brasileiros se tratam bem; são muito obsequiosos e hospitaleiros. $O$ viajante que chega a uma dessas casas é sempre bem tratado. Têm, todas elas, um quarto destinado aos hóspedes, onde se thes proporciona tudo quanto necessitam ou apetecem. Somente, sente-se falta do trato com as famílias, que nunca se apresentam ao estrangeiro. Assim, um forasteiro o é toda a vida.

No tempo da tirania, uma multidão de emigrados se dedicava ao ofício de fazendeiros [sic], quer dizer, mascates. Recorriam a campanha em todas as direções e, ainda que não ganhassem no negócio, conseguiam viver por que não tinham que gastar nada: tudo se lhes proporcionava nas casas onde paravam.

Prossigamos com a narração. Desde que havia sido feita a paz, o general Rivera se pusera em relação com o coronel Bento Manuel Ribeiro, que comandava os regimentos 40 e 42 da cavalaria imperial. Bento Manuel enviou, em missão especial ao acampamento de Rivera, um comissário de Guerra, de sobrenome Abreu e o capitão Cândido Azambuja, oficial de toda a sua confiança. Tratava-se de erigir em república a Província de Rio Grande, para o que solicitava o auxílio ou apoio da força de Rivera. Esse, que o que queria era se fortalecer para ir à Banda Oriental, exigia que Bento Manuel licenciasse os dois regimentos às suas ordens e, com eles, se the reunisse, comprometendo-se a auxiliá-lo com seu exército depois que se apossasse do mando em seu país.

Para acertar este ponto, despachou o general uma comissão ao acampamento de Bento Manuel, composta do doutor Obes e eu. Partimos acompanhados dos senhores Abreu e Azambuja. No primeiro dia de marcha, fomos parar em uma fazenda chamada São Rafael. Iam na frente o doutor Obes e o senhor Abreu; Azambuja e eu havíamos ficado meia légua atrás; quando chegamos era quase de noite.

Em uma esquina da casa, conversava um grupo de seis pessoas. Dirigíamo-nos a eles quando, ao aproximar-me, reconheci a Pancho Alzaga, vestido de seda com o maior luxo possível. Imediatamente retrocedi até onde havíamos deixado os cavalos.

- Que é isso, [sic] me perguntou Azambuja.

- Nada, nada, depois iremos; continuemos nossa conversa.

O doutor Obes, que espiava minhas ações, destacou-se do grupo e, chegando-se a mim, disse:

- Será nosso destino que sempre temos que nos encontrar com este homem?

- Não sei o que será, respondi; mas o que, sim, sei é que aqui me apeei, aqui vou dormir e daqui não me movo até amanhã, à hora de partir.

- Já esperava por isso, retrucou o doutor. Como faremos?

- Não sei como fará o senhor, mas eu farei como já disse.

- Mas, que pensarão os donos da casa?

- Que pensem o que queiram. Não hei de manter jamais relações amistosas com esse facínora.

$\mathrm{O}$ doutor Obes se foi. Chamou à parte o comissário Abreu; ignoro o que lhe disse, mas o certo é que Alzaga desapareceu e os donos da casa vieram buscar-me.

Nessa noite celebrou-se ali a notícia da paz. Já disse que os brasileiros são obsequiosos; nos ofereceram uma mesa esplêndida que durou até às 12 da noite, brindando aos benefícios da paz, à pátria, ao imperador, etc. Qual não seria a mortificação e talvez os remorsos que esse fato despertaria naquele desgraçado, ao ver-se excluído da nossa sociedade! 
Logo que nos pusemos em marcha, no dia seguinte, o comissário Abreu me atacou fortemente para que the dissesse o que havia com esse homem. Neguei-me a satisfazê-lo. Não quero - respondi - arrebatar a hospitalidade que lhe concedem aqui. Entre outras coisas, o senhor Abreu me dizia: "não é mera curiosidade o que me move"; aduzindo que lho haviam recomendado de Itaqui, que vivia em sua casa, em família, mas que tinha três filhas e ansiava saber a quem hospedava em seu lar. Contudo, me mantive firme apesar de suas razōes, que no fundo considerava justas.

Vendo-me fustigado, encurralado, em fim lhe disse:

- Quer o senhor ser portador de um recado para ele?

- Por que não, me respondeu.

- Pois declare a ele que digo que não seja covarde, que engula o cano de uma pistola, que é a única coisa que lhe resta para fazer neste mundo. ponto. ${ }^{1}$

- Ó senhor! isso é muito! [sic] repetia Abreu; mas eu não quis me afastar desse

Continuamos a marcha e fomos encontrar a Bento Manuel acampado no arroio de Zasquen.

A nossa missão não teve bom resultado e, depois de quatro dias de demora, regressamos ao exército, que encontramos na estância do Padre, onde havia feito alto à espera do resultado.

Depois disso, continuou a marcha até os povoadinhos de São Vicente, onde permanecemos muitos dias ocupados em reunir e despachar grandes tropas de gado daqueles criadouros, não obstante ser o que produzem pequeno, posto que não engorda nunca a menos que se lhe dê sal. Assim é que todas as grandes fazendas servem só para isso. Depois, há que inverná-los em outros lugares.

Foram retiradas, também, as famílias dos povoados daquela parte e as dos da costa do Uruguai se reuniram à outra divisão.

Cada redução ou tribo marchava como em procissão, conduzidas pelos anciōes, que levavam os santos principais. O povo conduzia uma multidão de santinhos. $\grave{A}$ frente ia a música. Cada tribo tinha a sua, composta de violinos. Os músicos são também os cantores.

As duas divisões se reuniram na costa do Ibicuí.

Calculava-se em cem mil cabeças de gado o que se arreava. Ali havia 28 carretas carregadas, trazidas pelo capitão Magariños. Levavam objetos do culto e até os sinos se dizia que continham muitas riquezas (não o creio).

Logo que chegamos ao Ibicuí, começou a efetuar-se a passagem, com muito trabalho porque o rio é muito largo e estava cheio.

Teve-se notícia de que o exército imperial se reunia para estorvar-nos a saída, a menos que se largasse o gado e puséssemos os índios em liberdade. $\mathrm{O}$ ponto de reunião era Alegrete, onde já se achava o marechal Sebastião Mena Barreto.

O general Rivera, que calculou que teria muitas demoras naquele passo, mandou-me em comissão a Alegrete para entreter quanto pudesse o marechal e seu exército, a fim de ter tempo para transpô-lo.

As minhas instruções estavam reduzidas a fazer reclamações sobre essa reunião de forças, formular alegados e suscitar questôes de todo o gênero.

${ }^{1}$ Em 1838, sendo major general do exército de Lavalle em Corrientes, tive o desgosto de ter que expulsá-lo do mesmo, a pedido de todos os chefes. Nessa vez também solicitava serviço. 
Quatro dias permaneci com o marechal; mas já não era possível demorar-me mais, pois por fim nada mais faltava a não ser que me expulsassem. Acreditava que era tempo mais que suficiente para efetuar a passagem do rio; mas, com grande surpresa minha, deparei com o fato de que a mesma não se havia praticado de todo. Tardamos ainda outros quatro dias para terminar de passar aquele imenso tráfico.

O marechal Barreto, que só esperava a minha saída de Alegrete, pôs-e em movimento duas horas depois. Não veio diretamente sobre o exército, mas sim adiantou suas marchas sobre um flanco, sem aproximar-se; manobrou, porém, de modo que ficamos cortados.

Para poder atender ao exército inimigo, o general Rivera mandou que tocassem o gado por diversos rumos, a cargo de comissionados, alguns dos quais, aproveitando a ocasião fugiram com as presas. Somente Pedro Espino lançou ao Uruguai, para passar a Entre Rios, 14.000 cabeças! O general queria fazê-lo seguir e fuzilar, mas atenções de outro gênero o fizeram abandonar a idéia.

O marechal Barreto, situado em Touro Passo, nos tinha encerrados.

Os exércitos se aproximaram. O Imperial constava de 3000 homens de cavalaria; o nosso, ainda que das três armas, era muito inferior.

Estávamos a uma légua de distância um do outro, em atitude hostil. A nossa linha formou-se em umas alturas para esperar o ataque, mas o brasileiro não se movia. As avançadas se tocavam; em uma delas, trocaram-se alguns tiros e tomaram-se dois prisioneiros.

Nesse estado, o general me chamou.

- Anima-se a ir ao campo inimigo? me disse.

- Como! Se me animo? Se me manda, irei.

- Veja você que é muito provável que o prendam.

- Como há de ser! Mas se me prendem ou me matam, o senhor me vingará.

- Antes que feche a noite, replicou com viveza, estará vingado ou sucumbiremos todos.

Tratava-se de evitar um rompimento que talvez haveria de comprometer a tranqüilidade do país e a paz que se acabava de celebrar. Era preciso obter passagem para a Banda Oriental, sem devolver o gado e os povos índios. Entretanto, a nossa posição era verdadeiramente crítica e até horrível.

O general Rivera se havia colocado em uma situação dificílima, como o diremos depois, com respeito aos governos de Buenos Aires, Brasil e Oriental e se via cortado, sem retirada, a menos que travasse uma batalha. $O$ interesse foi salvar o gado, sem cujo motivo teria tido tempo de sobra para sair do território brasileiro sem questão alguma.

O General deu-me suas instruções, encarregando-me de falar alto e forte, de não economizar ameaças e de descobrir e calcular a verdadeira força do inimigo.

Havia chegado de passeio um comandante Espeche, de Corrientes, trazendo dois soldados uniformizados à correntina. Deu-me esses dois homens para escolta, com a finalidade de fazer entender que nos haviam chegado dois esquadrões correntinos de auxílio.

Estavam no exército duzentos índios charruas. Mandou vir o cacique chamado Piru tape, de estatura gigantesca, e o fez montar seu melhor cavalo, que era um mouro parelheiro. Tirou da algibeira um lenço de seda escarlate para servir de senha. 
Segundo as instruções, o cacique não devia apear-se do cavalo. Se os brasileiros me tomavam prisioneiro, atiraria o lenço ao índio, que fugiria de rompida. Este seria o sinal de carregar com o exército e empreender o ataque.

$\mathrm{O}$ índio me havia sido recomendado por valente, mas portou-se como um covarde. Pouco faltou para que sua conduta causasse um conflito, que poderia ter conseqüências terríveis e desastrosas.

O campo que mediava entre ambos os exércitos era muito dobrado. Eu me aproveitei dessa circunstância para seguir pelas quebradas e montes. Estava já à vista do exército inimigo e havia descoberto a maior parte de sua força, quando fui percebido por uma avançada, que se despencou a toda a brida de um cerro, onde estava situada, e me rodeou.

Toda a partida trazia a carabina na mão em atitude de fazer fogo. Piru, ao ver isso, rompeu pelo meio no mouro voador, fugindo como um gamo e foi dar o alarma ao exército, onde entrou gritando: Agarraron oficiá; mataron oficiá, repetia. Chegado à presença do general, não expôs mais razão que a que havia dado aos brados.

Rivera mandou tocar generala e acender as mechas da artilharia, para avançar sobre 0 inimigo.

Afortunadamente, chegaram ao campo nesses momentos, com licença do marechal, o coronel Calderon e o tenente Azambuja. Um deles íntimo amigo de Rivera, com quem havia servido em outro tempo, e o outro seu afilhado muito querido. O general chamou-os e disse: "Ouçam o que diz o cacique. - Se é certo que mataram o meu enviado e até às quatro da tarde eu nâo tenha notícias dele, a essa hora vocês serão fuzilados". E desde aquele momento os pôs presos e incomunicáveis.

$\mathrm{O}$ movimento do exército foi suspenso devido às seguranças que davam, tanto Calderon como Azambuja, de que era impossível que me houvesse sucedido algo. Que o índio se tinha assustado debalde, sem motivo, ou era um grande maroto.

Não se equivocavam; era justamente o que havia passado. Tanto esse selvagem, como todos os charruas, tinham um temor pânico dos brasileiros e os detestavam, por que índio que pegavam matavam no ato.

\section{VI}

A partida que me havia detido me fez retroceder até a avançada, cujo comandante era um capitão Carneiro, a quem havia conhecido quando estive em Alegrete.

Assim que me viu fiquei livre e, longe de me tratar como inimigo, empenhou-se fortemente em que eu devia de almoçar com ele uma perna de carneiro oferecida por Carneiro, [sic] mas como eu conhecia a urgência do caso, the pedi que me mandasse o quanto antes à presença do marechal. Enquanto estava ali, deu parte do ocorrido. A contestação foi que me levassem.

$\mathrm{O}$ meu amigo Carneiro não quis usar comigo das formalidades de estilo, com que se recebem os parlamentários, mas eu observava que ia sendo levado por lugares em que não podia descobrir a força contrária.

Chegando à presença do marechal, fui recebido com toda a cordialidade de amigos. Ele estava com o coronel José Rodrigues Barbosa, cavalheiro muito distinto e amável, de quem ficamos depois muito camaradas.

Quis dar parte de minha comissão e o marechal me disse: não, almocemos primeiro, tempo há para falar de coisas. [sic]

- Não, senhor marechal - repliquei - não aceitarei de modo algum seu obséquio, sem antes saber se somos amigos ou inimigos. 
- Havemos de ser amigos, respondeu.

- Pois então, quero antes de tudo a segurança de que teremos livre o Touro Passo para a retirada.

- Não há dúvida, disse: o passo estará livre tão logo o seu general largue o gado e ponha em liberdade os índios.

- O gado - retruquei - foi tomado em tempo de guerra e não será solto. Os indígenas são livres: esse direito eles adquiriram com a nossa entrada nas Missões e estão indo por sua própria vontade.

O marechal replicou então: - pois eu tenho que cumprir as ordens do meu governo, que são de deixar sair unicamente o exército: fora daí nada. [sic]

- Pois eu - redargui - tenho que cumprir a que me deu o general, que é dizer a V. Excia. que, se no término de duas horas não se franqueia o passo, a linha está formada como se pode distinguir daqui: a artilharia, com a mecha acesa; três mil homens das três armas, inclusive dois esquadrões de correntinos - pois deles são esses soldados que V. Excia. vê - cairão sobre o seu exército, passarão por cima de seus cadáveres e, conseqüentemente, em nome do general-em-chefe do Exército do Norte e do governo da nação, faço a V. Excia. responsável não só pelo sangue que se vai derramar, como por todas as ulterioridades da nova guerra em que nos vamos envolver por sua culpa.

O marechal levantou-se como se tivesse sido picado por uma víbora.

- Ó senhor! disse: isso é muito. [sic] Por culpa minha? não: são as ordens que eu tenho recebido, $[$ sic $]$ porém escute senhor Pueyrredón, não sou amigo da guerra, não tenho ganas de brigar. [sic] o Frutos [sic] me conhece, conhece o meu caráter; mas, o que hei de fazer? Ponha-se no meu lugar, são as ordens. . .

- Há que eludi-las, senhor marechal. Pior será o que indubitavelmente vai acontecer, porque, não o duvide, o exército vem passar hoje mesmo e passará, pois se compõe das três armas e V. Excia. não tem mais que cavalaria.

O marechal refletiu e depois de um momento de silêncio: Não, não pode ser; é preciso que as ordens se cumpram. [sic]

- Pois nesse caso, já nada tenho o que fazer aqui. Retiro-me, senhor marechal: dentro de duas horas nos veremos neste mesmo campo, não já como amigos mas combatendo - e ao dizer isto levantei-me, ajuntando: o exército só espera a minha volta para marchar. E peguei o meu quepe.

O marechal levantou-se, também, dizendo: escute, sente-se.

A partir daquele momento, senti que tinha ganho a questão!

- Porque, continuou, uma das coisas que torna difícil a minha posição, é que não sei com quem hei de tratar; porque tudo se sabe. Quem são vocês? Qual é o seu governo? Os senhores são uma horda de homens errantes. Frutos desobedeceu ao governo de Buenos Aires; o da Banda Oriental não o quer receber; nós temos ordens de persegui-lo; assim, pois, a quem obedecem? de quem dependem?

- Do governo oriental - respondi sem trepidar - cujo reconhecimento o general acaba de receber. $\hat{\mathrm{E}}$ certo que estivemos alguns dias nessa espécie de interdito, mas não que Rivera haja desobedecido as ordens do governo geral. O que fez foi declarar que se retiraria para a Banda Oriental, mas já digo: hoje dependemos desse governo como poderá V. Excia. certificar-se de imediato.

- Sendo assim, Rodrigues, que fazemos?

O coronel Rodrigues não fez mais do que encolher os ombros.

Vi que era o momento decisivo e tornando a por-me de pé: - senhor marechal disse - o meu tempo é muito curto: um sim ou um não, é quanto necessito. 
O marechal levantou-se, chamou à parte o coronel Rodrigues, falaram um bom momento em voz baixa e retornando com cara satisfeita: vamos! - exclamou - já somos amigos e já não depende de mim senão de seu general: que solte a metade do gado e celebraremos uma convenção para fazer constar que por um convênio foram restituídas essas reses.

- Isso já está feito, senhor marechal. No passo do Ibicuí ficou mais da metade do tal gado; outra parte se dispersou depois; mas, do que ainda resta, nem uma vaca se soltará.

- Está bem, senhor, passem em paz, porém vamos almoçar; depois redigiremos os capítulos da convenção. [sic]

Eu estava apurado por regressar, mas não houve meio de me excusar nem de apressar o almoço, que foi um verdadeiro banquete.

Tanto o marechal Barreto como o coronel Rodrigues Barbosa eram cada qual mais amáveis, de um trato lhano, franco, amistoso e de bom humor, pelo que passei com eles momentos muito agradáveis.

Durante a conversação me disse, entre mil coisas engraçadas, falando do general Rivera: Ora, senhor Pueyrredón, o senhor não conhece o Frutinho; ele é meu compadre: porém é bom diabo, é muito velhaco. [sic] Era a primeira vez que escutava esta palavra aplicada a um homem: me fez rir e nunca mais a esqueci. Também me causou admiração o luxo do serviço e a cozinha. O primeiro era todo de prata; a segunda excelente e com deliciosos vinhos.

Depois da comida, foram redigidos alguns capítulos da Convenção, ficando reservado ao general agregar ou suprimir os que the conviessem, mas quase nada foi alterado.

Despedi-me desses senhores e regressei ao nosso acampamento a meia rédea.

Quando cheguei, surpreendeu-me ver o exército no mesmo estado ou formação de batalha em que o deixara.

Eu havia pedido ao marechal que, por meio das avançadas, fizesse chegar a notícia do ajuste ao nosso exército, o que não fez.

$\mathrm{O}$ coronel Rodrigues disse-me depois que não o haviam feito para deixar-me a satisfação de anunciá-lo eu mesmo.

Ao chegar, o general chegou-se a mim muito contente: - Homem - me disse - já não acreditava vê-lo mais; o índio Piru contava que o haviam morto. - É um índio pícaro, covarde, contestei. - E como estamos? Há paz ou há guerra? - Há paz, senhor, tudo está acertado. - Bem acrescentou, não esperava menos de meu negociador; logo me contará tudo o que houve, mas, antes, vá por em liberdade o Calderon e o Antonico, meu afilhado, que os tinha prisioneiros até saber de você.

Fui correndo fazer isso. Calderon me recebeu frio e sério. Azambuja me abraçava, me fazia carinho e chorava como uma criança. Pobre moço: estava convicto de que ia ser fuzilado. - Muito lhe agradeço - me dizia - o que me fez; mas o meu padrinho há de me pagar, pois não devia ter feito isso comigo.

A alegria do exército foi grande e mandou-se retirar a tropa da linha.

\section{VII}

Nessa mesma noite, acabou-se de redigir a capitulação e comissionou-se o coronel de engenheiros Eduardo Trolé para passar ao campo brasileiro e assinar a que se chamou Convenção de Ibebeambe: nome do arroio onde estava acampado o exército imperial. 
No dia seguinte tudo estava concluído. O coronel Rodrigues veio visitar-me: eu não tinha com que obsequiá-lo. Nosso exército - como são todos os nossos - era de pobres, pouco menos que de mendigos, e como elogiasse um cavalo barroso que eu havia levado de Entre Rios, fiz-lhe presente dele. Quando da emigração, tive o gosto de conhecer sua família em São Gabriel. Lembravam-se muito do cavalo, que Rodrigues estimava demais pela rareza do pelo. Esse oficial morreu afogado durante a guerra com os Farrapos.

Livre já de todo o cuidado, o exército pôde continuar sua retirada, sem obstáculos, para a Banda Oriental.

Mas, antes de dar conta de outras ocorrências, é preciso dizer qual era a verdade das coisas a respeito da posição em que se havia colocado Rivera.

Pelo tratado de paz, as Missões deviam ser restituídas ao Brasil. O governo nacional ao comunicá-lo ao general Rivera, ordenou-lhe fazer a sua entrega, repassar o Uruguai, situar-se em Iapeju, um dos povos das Missões ocidentais, e esperar ali a incorporação de uma divisão de mil homens, que ficava na Banda Oriental sob o mando do general D. José Maria Paz, e outros reforços que se lhe enviariam para expedicionar ao Paraguai e cujo comando lhe oferecia, ou melhor entendido, o lisongeava, por que abrigava desconfianças. Mas Rivera, que também desconfiava das ofertas, formou então a resolução de não voltar a seu país; não sem antes ter explorado a opinião do exército para não entregar as Missões: porém, não encontrou apoio. No entanto, desobedecendo as ordens do governo geral, mandou tirar os bens dos povoados, as famílias e o gado, depois de feita a paz.

Já dissemos que desde o arroio de Itu havia mandado o major-general Escalada apresentar-se ao Governo Oriental para oferecer submissão e serviços com todo o seu exército.

Tanto o Governo como a Assembléia estavam até então na vila de Canelones.

O governo do Estado Geral José Rondeau [sic], não se atrevendo, por si mesmo, a arcar com semelhante responsabilidade - tanto mais quanto conhecia quão espinhoso era o negócio, numa época em que dominava o partido de Lavalleja - submeteu o assunto à Assembléia, que o rechaçou, opondo-se à entrada de Rivera naquele Estado. Muito poucos amigos tinha este naquela corporação e ainda que apresentassem o assunto por várias faces, trazendo à discussão o nome de Rivera, jamais puderam conseguir nada. Cada vez que isso sucedia, levantava-se uma grita espantosa e não se ouvia senão: que busca esse facínora, dizem que pisou o território: que saia, que seja posto fora da lei, etc. Era pois impossível conseguir alguma coisa daquela gente. O coronel Escalada havia desesperado, vendo que suas repetidas gestões não produziam resultado algum.

Tal era o estado das coisas, quando os brasileiros com seus três mil e quinhentos vieram estorvar a nossa saída das Missões. Tinha razão o marechal Barreto quando dizia que éramos uma horda de homens errantes, sem governo e sem pátria, e ao responder-lhe que estávamos reconhecidos pelo Governo Oriental, afirmávamos uma coisa que não era certa.

Mais de quatro meses estivemos nessa desesperante situação, mas ela era um segredo para o exército, que não o penetrou jamais.

Antes de chegar à fronteira oriental, fizemos alto na costa de Aurupá, campo deserto, ocupado só pelos Charruas, na espera de que se desenvolvessem os planos que Rivera havia preparado a fim de entrar em seu país.

O general era habilíssimo e de uma imaginação fecunda para a intriga, que manejava com destreza; além do que, poucos homens o igualavam na audácia em efetuá-las. A sua máxima favorita era que todos os meios são bons, quando com eles se consegue o objeto proposto. 
VIII

No mesmo dia $1 .^{\circ}$ de dezembro, em que era nomeado um governador efetivo para a Banda Oriental, estalava uma revolução em Buenos Aites para derrubar outro governador.

Seria em meados desse mês quando, pela hora da sesta, chegou um chasque com correspondência para o general, o qual logo que a leu, veio à minha barraca despertar-me para que o convidasse a tomar mate. Ali se pôs a ler e, dirigindo-se a mim, me disse: "Tem que me dar os parabéns, por uma fausta nova", e dando-me para ler deparei com a notícia: era o movimento de $1 .^{\circ}$ de dezembro! As cartas eram do senhor Domingo Cullen, de Santa Fé. Na primeira dizia: "Em Buenos Aires ocorreu uma revolução; uns dizem que encabeçada por Alvear, outros que por Lavalle." Na segunda, lia-se: "Parece fora de dúvida que Lavalle é quem encabeça as forças da revolução. Dorrego fugiu para a campanha para reunir-se com D. Juan Manuel Rosas. Lavalle saiu em sua perseguição; haverá guerra civil... !" - E disto quer que lhe dê parabéns? Não senhor: dar-lhe-ei os pêsames. Não me agradam as revoluções; além do mais sou portenho e não posso gostar que o meu país se envolva numa guerra intestina. - Vejo que não refletiu. Você é meu amigo e deve alegrar-se, por que isso nos salva, pois sabe muito bem qual é a nossa atual posição. Agora alguém nos há de procurar: se nos chama Alvear, lhe diremos que obedecemos a Dorrego e se este, que a Alvear ou a Lavalle, e me descarto das responsabilidades que você sabe. De todos os modos, essa revolução veio para salvar-nos; eu tirarei partido da situação.

Passamos depois a falar dos três chefes mencionados. - A Alvear conheço muito - me disse - aos outros não tanto; mas, pelo que tenho ouvido deles, creio que o seu país se vai ensanguentar: por que se Alvear captura Dorrego, o fuzila e vice-versa. - E Lavalle? perguntei-lhe. - Ó! esse fuzilará os outros dois.

Estávamos nesta conversa, quando deu de passar perto dali o coronel Trolé. Você que é amigo dele, chame-o - me disse. Posto a par da notícia, Trolé mostrou-se caloroso partidário de Lavalle e entre outras coisas disse: a esta hora, Lavalle, feita a revolução, estará em sua casa, porque tudo o que quer é para o seu país, nada para si.

Mais tarde chegou ao quartel-general o senhor Chilavert, o qual mostrou-se muito partidário de Alvear.

Rivera, que de tudo tirava partido, despachou dois dias depois a Trolé, por via de Colônia, onde devia embarcar para ir pôr-se de acordo com Lavalle, caso esse fosse o chefe da revolução, e, a Chilavert por via de Entre Rios, devendo embarcar-se pelo Arroio da China para fazer o mesmo, no caso de Alvear. Ao mesmo tempo, o doutor Obes partiu para a Banda Oriental a fim de desenvolver ou preparar um plano de outro gênero, mediante o qual esperava o nosso astuto caudilho obter o seu regresso ao dito Estado.

Alguns dias depois da partida do doutor Obes, me disse: - "Necessito-o para outra comissão, que só pode ser desempenhada por um amigo: vou mandá-lo até onde está o governo. Dentro de uma hora, deve partir."

Recebi as instruções e uma carta credencial que me afiançava, além de outra circular que dizia o seguinte:

\section{"A todos os meus amigos da campanha:}

Rogo a todos os meus amigos que proporcionem ao portador desta o melhor cavalo que tenham, para o desempenho da comissão que leva, que é da maior importância. Campo de Aurupá, etc. 
Nesse mesmo dia cheguei à povoação de Belém, a primeira da Banda Oriental por aquela parte. Ali encontrei o doutor Obes e o coronel Trolé. O primeiro ocupado com sua missão, que não era outra que a mesma que me levava a Canelones. Trolé, atrasado, por falta de meios de mobilidade.

Havia sido recebido ali o boletim de Lavalle, no qual dizia que havia sido fuzilado o governador Dorrego por sua ordem, e a parte da ação de Navarro.

Principiava a cumprir-se a predição do general Rivera!

Mandei ambas as peças a esse, fazendo regressar um dos vaqueanos, que me havia dado, com uma carta em que fazia reflexões sobre aquele sucesso.

Fiquei sabendo, depois, que a impressão que lhe causou a minha carta foi tal que esteve dois dias encerrado e que havia chorado, apesar de não ser amigo de Dorrego.

\section{IX}

Desde que pisei o território Oriental, não segui caminho algum: cortava campo. Era muito curto o prazo que me havia sido dado; mas, a recomendação foi tão eficaz que, em lugar de caminhar, voava.

Não apresentei a carta em parte alguma em que não me dessem cavalo. Muitas vezes montei os parelheiros que tinham em compostura e era despachado a qualquer hora da noite. Isso me deu uma idéia do prestígio do nome daquele general, na campanha.

Em quatro dias e meio havia atravessado todo o Estado Oriental e tinha marcado a hora em que devia apresentar-me em Canelones. Cheguei duas horas antes e esperei que fossem às 8 da noite, hora em que me apresentei às portas da casa de governo e me fiz anunciar por um ajudante-de-campo, o qual me informou: - "o senhor governador está encerrado com os ministros". Esse mandou perguntar de quem se tratava: - Diga-lhe contestei ao ajudante-de-campo Magariños - que é um comissionado do general Rivera que vem do Exército do Norte em comissão urgentíssima.

O Governador saiu a receber-me e admirou-se muito ao encontrar-se comigo: "Ó Pueyrredón! você aqui? que novidades há? " - Uma muito grande, senhor governador: aqui está esta carta que me acredita perante V. Excia. - e lhe entreguei a minha credencial, na qual se pedia ao governo que desse inteira fé e crédito a quanto eu the dissesse.

Desde aquele momento comecei a desempenhar a minha comissão.

Logo que leu: - e bem? - prorrompeu - que novidade há? - Senhor, respondi, uma revolução está sendo preparada para derrubar o governo de V. Excia. Leonardo Olivera, com 800 homens, carregará sobre este ponto. A sedição tem ramificações em outras partes. Oferecem o comando ao general Rivera, mas ele, longe de aceitar, me envia junto a V. Excia. a fim de por à sua disposição o Exército do Norte para sustentar a autoridade; o qual se movimenta em marcha forçada, sem prejuízo dos esquadrões que saíram já á la balija, sob o mando do comandante D. José Augusto Pozolo, que tem ordem de caminhar dia e noite.

- E você viu partir esses esquadrões?

- Não senhor, mas ouvi dar a ordem, que era de partir ao término de duas horas. Eu tive a de sair em uma, assim pois, é como se o tivesse presenciado. Ademais, o general me encarregou: "assegure ao governo que já estão em marcha e que têm ordem de voar".

- Com que então, os revolucionários oferecem o mando ao general Rivera?

- Sim senhor. Mas, longe de aceitar, contestou que será o primeiro a sustentar o governo legal, aconselhando-os, ao mesmo tempo, a desistir de seu intento, por que do contrário cairá de imediato sobre eles. 
A cara do governador, muito enfarruscada quando cheguei, ia pouco a pouco desanuviando e, por último, mostrou-se risonho e prazenteiro.

- Já sabemos da revolução, replicou; o governo tem notícias dela.

Fazia uma hora que havia recebido os avisos vindos de Maldonado. Não podia pois duvidar de sua existência.

Seguramente, haviam mandado buscar os deputados da Assembléia, por que o governador chamou o ajudante e lhe deu ordem de mandar por cadeiras no pátio para aqueles e de que ninguém entrasse onde estávamos, nem onde estavam os ministros. Em seguida dirigindo-se a mim, disse: - Você fica aqui. Fechou a porta à chave e foi para onde estavam os Ministros Muñoz, Giró e Garzon, levando na mão a credencial.

Dentro em pouco, voltou muito contente aonde eu estava e disse: - Pueyrredón amigo: quer tomar um licor ou qualquer outra coisa? - Eu tomaria um mate, respondi. - Não, retrucou, por agora não; depois tomará. Não convém que entre ninguém aqui - e voltou a retirar-se. Um momento depois, trouxe uma garrafa de água e um prato de favos. - Entretenha-se com isso até que possa alcançar-lhe o mate. Fazia tudo isso do modo mais prazenteiro e amável.

Tornou a sair, deixando-me sempre incomunicável; mas, vinha a cada momento fazer perguntas, quase todas sobre os dois esquadrões. - Está seguro - me dizia - de que terão marchado?

- Muito seguro, senhor governador. Hoje já têm quatro dias e meio de caminho.

- Pois onde está o exército, uma vez que você veio em quatro dias e meio?

- Muito longe, senhor, em território brasileiro; mas se eu cheguei tão depressa, é porque tinha ordem de voar e andar dia e noite. Assim o fiz, mediante esta recomendação, que me serviu de um modo tal que montei os melhores cavalos do trajeto e várias vezes o parelheiro da estaca: com uma recomendação semelhante, não há distâncias. Ademais seguia a rumo, para o que me deram excelentes vaqueanos.

O governador pediu a circular e tornou a sair com ela.

Todas essas coisas eram conducentes e próprias para causar efeito.

Quando regressou foi para renovar as perguntas.

- Onde é Aurupá?

- Cerca de 20 léguas além do Quaraí.

- Que força tem o exército?

- De dois mil e oitocentos a três mil homens de tropa, fora 800 índios arregimentados.

- Que mais traz?

- Traz 150.000 cabeças de gado, 20 carretas de objetos de valor dos povos e de 10 a 12 mil famílias.

O governador estava assombrado: parecia sonho o que ouvia.

Depois de escutar tudo isto sem dizer palavra, se foi para dentro. Uma hora, pelo menos, demorou para voltar e então me disse: Tudo está acertado.

- Aqui está o tinteiro e o papel para que escreva ao general que foi aceito o auxílio que oferece; que ele fica reconhecido como pertencente ao Estado, com todo o seu exército; mas que apresse as marchas e repita a ordem a esses esquadrões para que voem, se for possível. Diga-lhe, também, que o governo autoriza a você para avisá-lo, sem prejuízo de fazê-lo por ofício depois. 
- Agradeço ao governo, - respondi - pela confiança que deposita em mim, mas não sou bastante autorizado para uma coisa de tanta gravidade e transcendência. Eu não devo escrever: é o governo que deve fazê-lo.

- Fá-lo-ei depois - contestou - como já disse; mas, por agora, faça-o você. Não the expliquei que comunique que o faz autorizado por mim?

- Sim senhor, V. Excia. explicou, mas insisto em que não sou competente; o general dará mais crédito a uma palavra do governador que a vinte minhas.

Insistindo sempre em que eu escrevesse: - Bem, senhor - disse-lhe por último vou escrever, mas o senhor governador dignar-se-á de pôr ao pé da minha carta que tudo o que ela contém corresponde ao que me foi ordenado por V. Excia. - Está bem, disse, escreva.

Escrevi, ali mesmo, uma carta contendo em resumo a ordem que havia recebido para transmitir, à qual o governador agregou, sob sua assinatura, ser o mesmo que me havia dito. Quando vi que assinara, pensei com os meus botões, já está atingido o objetivo: caíram no logro. O blefe será descoberto, mas terei tempo de sair daqui e o general de entrar com seu exército. isso.

- Agora mesmo, disse-me o governador, é preciso que despache um chasque com

- Senhor, o único homem que ficou está morto de cansaço, mas o coronel Escalada trouxe uma escolta. Ele pode mandar um homem.

- Pois, peça-o a Escalada; por que aqui não tenho a quem enviar.

Abriu, então, a porta que dava para o pátio, onde se encontravam sentados todos os membros da Assembléia e os ministros. $O$ governador apresentou à reunião o seu amigo Pueyrredón, que havia sido seu companheiro de campanhas em outros tempos.

Fez-me tomar assento naquele terrível círculo, onde previ que ia ser espremido e começou, com efeito, um verdadeiro interrogatório, um inventário, uma inquisição. Quem queria me dirigia uma pergunta sobre o número de tropas, de riquezas, de gado, de famílias. Com que admiração ouviam dizer cento e cinquenta mil cabeças de gado! ó! que riquezas para o nosso país, exclamava um; e dez ou doze mil famílias: que colônias vamor formar! Mas outros, e não eram poucos, duvidavam da veracidade da relação, que classificavam de exagerada. - Não se terá você equivocado? me diziam. - Creio que não, senhor, por que assim o diz todo o exército; embora eu não as tenha contado. Outros me dirigiam palavras capciosas, para ver se me pilhavam em alguma contradição, as quais me punham em aperto, por que não estava preparado para isso.

Tudo havia sido muito simples enquanto tive que tratar só com o governador. Trazia a lição bem estudada. Não assim com os da Assembléia por que, além de serem muitos, tinham interesse em confundir-me: algumas vezes me vi em bárbaros trabalhos, mas consegui bem ou mal me safar.

Havia alguns que se via que não acreditavam em nada. Ao menos, assim o manifestavam; mas como a maior parte engoliu o anzol, estes mesmos combatiam os incrédulos.

Por fim, saí daquele tribunal e fui pedir ao coronel Escalada um soldado, para mandar de chasque, o que me foi negado. Por essa razão, tive que fazer partir o vaqueano que havia trazido e ficar só em Canelones, de onde teria, talvez, que sair quem sabe como, pois quando se puchasse pela manta ficaria a descoberto o pastel e então não poderia sem perigo permanecer ali. 
A verdade das coisas era que jamais existiu semelhante revolução. É certo que haviam tentado o coronel Olivera para que a intentasse, mas esse negou-se redondamente.

O general Rivera, que não tinha outra retirada a não ser para a Banda Oriental, devia entrar nela por gosto ou à força. Forjou, pois, uma revolução para apresentar-se como o homem fiel, o sustentador da autoridade; o que era melhor que ir depô-la. O chasque que veio de Maldonado e outros avisos que foram recebidos eram forjados; falsa a comunicação que trouxe; e tudo foi combinado de maneira que quando eu chegasse já o Governo devia ter a notícia. Por isso, me havia sido determinado a hora precisa em que deveria me apresentar a esse.

Era impossível não cair na cilada. O exército, que eu lhes assegurava ser de três mil homens, não passava de mil e quatrocentos a mil e quinhentos; os 800 índios arregimentados seriam 200 lanças missioneiras, pois os charruas haviam retornado ao deserto; as 150.000 eabeças ficaram reduzidas a 44.000 , únicas que se salvaram; as 10 ou 12 mil famílias não passavam de duas mil almas, entre grandes e pequenos. As 20 carretas que trouxe D. Bernabé Magariños, existiam, mas na maior parte continham santos, sinos ou objetos semelhantes, bons para servir de sinuelo para aqueles indígenas tão fanáticos e apegados a essas coisas.

Passados poucos dias, já começou a correr a voz de que tudo aquilo era uma fábula inventada para que Rivera penetrasse em seu país. O meu nome, como deve supor-se, principiou também a entrar em discussão, de um modo pouco favorável. Chegou a extremo de eu ser aconselhado, pelo próprio coronel Escalada, pelo cura Larrobla e outros amigos, a partir. Eu mesmo não estava tranqüilo e esperava saber que o general se aproximava para ir-me, como o fiz, indo reunir-me com ele em Durazno, de onde fomos acampar no arroio da Virgem, em cuja paragem deu um banquete de despedida a todos os chefes e of iciais.

Estando ali, chegaram dois comissionados, um depois do outro, mandados de Buenos Aires para tratar com Rivera: o primeiro foi o coronel Trolé, o segundo o doutor Juan Andrés Gelly.

Saindo do arroio da Virgem somente com uma escolta, dirigimo-nos a Canelones, havendo-nos feito preceder pelos esquadrões de Pozolo, que, servindo de vanguarda, se situaram em Santa Lúcia.

Ao chegarmos em Canelones, saiu o Governador ao nosso encontro e pude observar que tinha havido mudança. Ia só com um ajudante-de-campo: ninguém mais o acompanhava.

Passados poucos dias, o governo foi trasladado para Aguada, onde Rivera foi nomeado chefe do Estado Maior Geral e lhe foram dados doze mil pesos para seus gastos. Enquanto ele os desfrutava, eu era quem tinha que sofrer com a má vontade dos ministros e de outros que não o eram, o que começava a me desgostar ao extremo e terminei por não me apresentar a nenhum deles.

Citarei um fato em prova do que me refiro.

O Governador querendo reconciliar Rivera com D. Manuel Oribe, convidou-os a almoçar juntos; não se consentiu em sua mesa a ninguém mais além de mim, porque assim o havia exigido Rivera. Esses senhores, depois de um discurso que lhes dirigiu o Governador, abraçaram-se friamente.

Concluído o almoço, subimos a um carro para ir a Montevidéu, onde visitamos o general Andrea (chefe da guarnição brasileira que ainda permanecia na praça); a Aduana, a Caridade e demais estabelecimentos públicos. Todo aquele dia foi empregado nesse passeio; mas, tanto na mesa como na carruagem, Oribe jamais me olhou de cara: tal era a 
prevenção em que me tinham os que não se atrevendo a chocar-se com o general, o faziam comigo.

Por esse tempo, encontrava-se em Montevidéu o general San Martin. Fui visitá-lo e me fez uma acolhida cheia de agrados, apresentando-me a todos os que estavam na mesa do Hotel, dizendo:

- "apresento-lhes um dos meus rapazes". Em seguida, começou a fazer perguntas sobre os meus ferimentos, como para fazer saber que eu as havia recebido na Guerra da Independência.

Depois disso, eu o via cada vez que podia.

O governo do Peru o chamava; ele estava indeciso sobre o partido que tomaria; convidou-me a acompanhá-lo no caso de decidir-se a aceitar e prometi fazê-lo.

O general San Martin desaprovava a revolução de $10^{\circ}$ de dezembro.

Assim que se apresentou no porto de Buenos Aires, Lavalle mandou-lhe uma comissão, chamando-o e oferecendo colocar-se às suas ordens: o general negou-se e nem sequer quis desembarcar, regressando a Montevidéu. - "Eu não podia aceitar as suas ofertas" - me dizia um dia - "porque José de San Martin pouco importa, mas o general San Martin dá muito peso à balança e tu sabes que tenho sido inimigo das revoluçōes, que não me podia colocar a serviço de uma delas. Quando Bolívar foi ao Peru, eu tinha oito mil homens, podia sustentar-me, levá-lo de roldão; mas, era preciso dar o escândalo de uma guerra civil entre dois homens que trabalhavam pela mesma causa e preferi resignar o mando. Ao cabo, ao cabo, Bolívar queria o mesmo que eu."

O general Rivera me disse um dia: - Sabe quem está em Montevidéu? - Quem senhor? - O general San Martin. A quem mandaremos para saudá-lo? - A mim, respondi. - Ó, a você não! isso não pode ser. Todos sabem que foi meu agente junto aos portugueses. A praça ainda está ocupada por eles. Se o vissem ir, não deixariam de pensar que ia mandado por mim para tramar alguma coisa. Aqui eu tenho que andar com muito tino porque estes tolos (zonzos) ainda acreditam que sou português.

- Pois senhor, a dificuldade vai cessar confessando-lhe eu que já estive em Montevidéu e visitei o general San Martin. Logo que soube por D. Blas Despouy que ele lá se encontrava corri a saudá-lo. - Pois então - retrucou - nada impede que você vá saudá-lo em meu nome, oferecer-lhe os meus serviços e toda a minha valia; e, de passagem, fará o mesmo com os generais Balcarce, Martinez, o coronel Iriarte e o senhor Aguirre.

Esta comissão foi desempenhada no dia seguinte.

\section{XII}

Pouco depois, pediu-me o general Rivera que ajudasse o encarregado das repartições públicas na ordenação do Estado Maior, por qual motivo foi trazido à luz um recenseamento feito no ano anterior, sendo chefe político um senhor Melo, do qual resultava que a população daquele Estado constava então de 12.000 habitantes na Capital e 48.000 na Campanha, o que me pareceu bem pouco para uma república.

Todo o drama tem o seu desenlace e o que eu havia representado devia terminar, do modo como acabam os serviços que se fazem aos chefes de revolução. De pouco devia servir a lembrança da abnegação, do desinteresse, do sacrifício até de minha reputação, para um homem que já não necessitava de mim e tinhaque contemporizar com seus patrícios. 
A gratidão é uma carga que pesa. Por efeito de certa pendência que surgiu um dia na mesa, com um coronel de milícias chamado D. José Vidal, o general Rivera quis fazer sentir a sua autoridade para me obrigar a calar; autoridade que rechacei até com a ponta da espada. Por este motivo pedi o passaporte e regressei ao meu país, em meio à guerra do ano 29. Omito os detalhes desse lance porque, sendo puramente pessoais, a ninguém pode servir o seu conhecimento.

$\mathrm{O}$ que segue de meus apontamentos pertence a outra época e a outros sucessos.

\section{Manuel Alejandro Pueyrredón}

\section{Departamento de História}

Pontifícia Universidade Católica

do Rio Grande do Sul

Porto Alegre - Brasil

\section{NOTAS}

${ }^{1}$ SANGUINETTI, Marta Canessa de. Rivera "un oriental liso y llano". Montevidéu, Ed. Banda Oriental, 1976, p.107.

2 Idem, op. cit., p. 22.

${ }^{3}$ Bernabé Rivera, desde que se achou homem bastante, acompanhou D. Frutos em todas as suas andanças, inclusive na invasão das Missões em 1828.. Morreu em circunstâncias épicas, atropelando uma partida de charruas acompanhado, apenas, por um devotado amigo, Pedro Bazán, que também sucumbiu.

${ }^{4}$ SANGUINETTI, M.C., op. cit., p. 24 .

5 Abordagem mais recente da questão e novos enfoques em FLORES, Moacyr. Modelo Político dos Farrapos. As idéias políticas da Revolução Farroupilha. P. Alegre, Ed. Mercado Aberto, 1978.

${ }^{6}$ ACEVEDO, Eduardo. Anales Historicos del Uruguay. Montevidéu, Barreiro y Ramos, 1933, t.1, passim.

${ }^{7}$ Rincón de las Gallinas ou de Haedo: espécie de península formada pelas águas do Rio Negro e do Uruguai. Ali mantinha o General Abreu uma reserva de 6.000 cavalos, guardados por 50 soldados. Em 24 de setembro de 1825 esse destacamento foi dispersado por Rivera, no comando de uma força superior. Os animais estavam sendo arrebanhados quando cerca de 400 guaranis, componentes dos regimentos 24 e 25 de cavalaria, comandados por José Luís Mena Barreto e Jerônimo Gomes Jardim, começam a penetrar no Rincão em desordem. Além das marchas precipitadas que vinham efetuando, extenuantes para as montarias e milicianos, os dois coronéis se haviam desentendido por questões de preeminência no comando. Deixaram de tomar as menores precauções de segurança. Rivera, prevenido por seus bombeadores, caiu sobre a tropa brasileira, de surpresa, e a desbaratou. Quem não morreu, ou debandou ou depôs as armas, exceção feita do jovem Mena Barreto que com alguns companheiros resistiu até o último alento. v. CARNEIRO, David. História da Guerra Cisplatina. S. Paulo, Ed. Nacional, 1946 (Brasiliana, v. 246), p.52-56.

${ }^{8}$ MACHADO, Carlos. História de los Orientales. $3^{\text {a }}$ ed. Montevidéu, Ed. Banda Oriental, 1973, p.86: "Desertaron Oribe y Bauzá, luego de la caída de Montevideo. En la capital, Lucas Obes, Durán, Larrañaga, Llambí, Solano Antuña, Sierra, Pérez y Bianqui, rivalizaban en genuflexiones con el vencedor. Larrañaga recorrió dos leguas para recibir las fuerzas invasoras y poderles dar la bienvenida (se les cantó una misa 'en agradecimiento')." 
9 Segundo as "Notas Biográficas" de Rivera: "el sargento mayor portugués Bentos Manuel abusando de la buena fe con que el general Rivera se había prestado a las conferencias políticas. sorprendió a Rivera en el momento menos pensado, se apoderó de su persona, y le intimó terminan. temente que, se diera prisionero o firmara la pretendida incorporación... El general Rivera reputa ese día como el más infausto de toda su vida...”. apud Sanguinetti, M.C., op.cit., p.31.

${ }^{10}$ A captura de Rivera por Lavalleja é, pelo mínimo, muito suspeita. O próprio Rivera a nega indignado: "... yo no creo que el Gen. Lavalleja mande tal Sumaria de que he sido su prisionero porque en ese caso sería más criminal que yo en razón de haber confiado el mando de las principales fuerzas de la provincia haberse convenido conmigo ... Con ningún prisionero se capitula de ese modo y si se hace cómo se confía la suerte de un país a un prisionero...". (Carta a Julián de Gregorio Espinosa, 22.10.1826); apud Sanguinetti, M.C., op. cit., p.38/39.

A versão de Lavalleja é outra, conforme o depoimento de seu secretário, Lucas Moreno: "Cuando era secretario del general Lavalleja me contó que él y Rivera venían cayendo en un bajo en dirección opuesta y con el sombrero echado sobre los ojos; que hallándose a unas 25 varas de distancia levantó el (Lavalleja) la cabeza y fue entonces que Rivera lo reconoció, haciendo ademán de levantar el caballo petizón que montaba, con ánimo de dar vuelta y disparar, habiéndolo disuadido Lavalleja de su intento con estas palabras: "No dispare, compadre, que yo también tengo aguilitas'." O fato vem referido por MORENO, Eduardo. Apuntes de la Guerra Grande. Montevidéu, Barreiro, 1925, pp.9, 11, $31,123,287$. Muita lógica na explicação de um ou excesso de imaginação do outro?

${ }^{11}$ Os brasileiros, principalmente, custaram a aprender como se comportar perante o polifacético caudilho: até o fim da guerra, o círculo lecorista não perdeu a ilusão de vê-lo trocar de campo. Essa credulidade, aliás, provocava-lhe invariavelmente a hilaridade. Nicolás Hererra em carta a Lucas José Obes faz referência à "confiança pueril" que Lecor depositava em Rivera.

12 Cf. BARRIOS PINTOS, Aníbal. Lavalleja 'la patria independiente'. Montevidéu, Ed. Banda Oriental, 1976, p.43: "Su patriótica tentativa tuvo un desenlace económico muy deficitario para sus intereses. Se le embargó una estancia que tenía poblada en la costa del Santa Lucía Grande, sobre el paso de Fray Marcos - presumiblemente, la que, había sido de Antonio de la Torre, bisabuelo de Lavalleja -, poblada con mil cabezas vacunas y más de un millar de caballares; una tropa de nueve carretas con tres mudas de sus bueyes cada una de allas y una pulpería surtida de mercadería, establecida en las puntas del arroyo Clara."

${ }^{13}$ Cf. TORRES WILSON, José de. Oribe 'el drama del Estado Oriental'. Montevidéu, Ed. Banda Oriental, 1976, p. 63/64: "Gestada dentro de las fronteras del naciente Estado oriental, en la lucha de sus dos primeros presidentes, la Guerra Grande se convirtió, desde su mismo inicio, en un conflicto rioplatense - por la alianza de sus recién nacidos bandos, blanco y colorado, con los ya existentes partidos argentinos, federal y unitario - y terminó transformada en una guerra internacional al intervenir en ella potencias extranjeras como Francia e Inglaterra y, finalmente, el Imperio del Brasil. En su transcurso la independencia de la novel república se vio seriamente cuestionada y sólo empezó a ser posible otra vez - y en forma muy precaria - cuando, al final del conflicto, se restableció el equilibrio de fuerzas que la había originado en la Convención Preliminar de Paz de 1828. La prolongación y la dureza de la lucha - y la permanencia de las alianzas regionales por encima de fronteras - desdibujaron el embrionario ser nacional y dividıron a la población del territorio en dos parcialidades antagónicas que, aunque surgidas de posiciones políticas que implicaban contenidos ideológicos, se fueron tiñendo prontamente de una fuerte carga emotiva. A partir de entonces, blancos y colorados - bandos accidentales de los primeros años de nuestra vida independiente - empezarán a convertirse en dos tradiciones opuestas y en dos maneras distintas de entender y de sentir el país."

${ }^{14} \mathrm{Os}$ contingentes argentinos imobilizados às margens do rio Uruguai, a título de defender Entre-Rios de uma pouco provável invasão brasileira, só adentrarão a Banda Oriental depois dos principais sucessos das armas uruguaias. Cf. PALACIO, Ernesto. Historia de la Argentina. $7 .^{a}$ ed, Buenos Aires, A. Peña Lillo, 1974, t.1, p.291: "El Ejército de observación no pasaba todavía el río a la espera de los contingentes provinciales. La situación no urgía, puesto que los patriotas orientales mantenían en jaque al enemigo...." 
15 Cf. PALOMEQUE, Alberto. El General Rivera y La Campaña de Misiones (1828). Buenos Aires, Ed. Arturo E. López, 1914, p.167: "Todo esto disgustó 'al brigadier general don Fructuoso Rivera', decía Rodríguez 'como si aquel cuerpo fuese la propiedad de un individuo, y ha pedido su separación del ejército y pasaporte para pasar a la capital, que le ha sido acordado por el que subscribe, no hallando medio de conciliar las pretensiones de aquel general con los intereses nacionales, que ha debido consultar ante todo el que subscribe'."

${ }^{16}$ Cf. BARRIOS PINTOS, Aníbal., op. cit., p.59: "Por una carta de Rivera al deán Funes, del 28 de febrero de 1826 , se sabe que el 14 de agosto de 1825 habían surọido sus desacuerdos con Lavalleja, cuando éste designó a Andrés Latorre en calidad de coronel del Regimiento de Dragones de la Unión, quedando el brigadier inspector bajo las órdenes directas de Lavalleja. Así actuó en Sarandí. El relevo se hizo sin consultar a Rivera, que comandaba dicha división desde su creación en 1821 y en ella basaba su poder militar."

${ }^{17}$ Lavalleja criou esse e outros apelidos para o "compadre": "mulato palangana", "Wasinton Rivera", "Napoleón", "polilla de campaña", "facineroso", "loco", etc. Rivera retribuia com "ambicioso y miserable", "botarate", "necio hombre", "bruto e imbécil". Na manhã do dia em que faleceu, 22 de outubro de 1853, Lavalleja escrevera sua última carta a Rivera, começando com um "Mi estimado Compadre y amigo" e terminando com "se repite a Ud. afectuosamente compadre y amigo Q.S.M.B. Juan Antonio Lavalleja." Do exílio, no Rio de Janeiro, Rivera the havia escrito, por sua vez, manifestando-the: “. . yo jamás dudé de la nobleza de su corazón y sentimientos. ..". Tinham, pois, muito em comum.

18 Apud PALOMEQUE, Alberto., op. cit. p.191/192:

\section{"ORDEN}

Buenos Aires septiembre 15 de 1826

Habiéndose ordenado el arresto del brigadier general don Fructuoso Rivera para que respondiese en juicio público bajo las garantías que dan las leyes, a los cargos que deben formársele zobre datos relativos a crimen de alta traición, e infidelidad, y notándose que se ha ausentado de esta capital luego que supo se le buscaba, se le llama, cita, y emplaza, por este edicto, de orden del gobierno, para que en el perentorio término de 24 horas se presente a esta inspección general.

\section{Miguel Soler"}

19 Alguns trechos do boletim "Pueblos Alerta!", publicado pela "Imprenta de la Provincia," dão uma idéia do clima reinante:

"Pueblos: ved ahí el abismo que os estaba abierto por un hijo desnaturalizado de la Patria! Ved el punto a donde iba a parar la nefanda insurrección promovida en la provincia por joven Rivera! Reconoced en esta trama el hilo de la pérfida conducta de Calderón en $1825, y$ abominad a los traidores! Estas son las armas con que ha contado siempre el tirano del Brasil para unciros nuevamente al carro de vuestra ignominia; ésta la única esperanza a que ha librado el desagravio de su orgullo humillado en los campos de batalla [.. . ] La seducción, la intriga, el soborno, estaban en campaña y ya se complacía el malvado en el triunfo, y en su venganza, pero la Providencia que vela sobre nuestra Patria, ha transtornado los planes de la iniquidad. [.. . Mientras tanto, ese emperador insensato que ya se gloriaba en nuestra ruina, vé hoy trocada la escena, y trasladado á su imperio el teatro de la discordia y de la guerra civil, que él preparaba a nuestro suelo. Todo el Brasil arde en una conflagración general: las provincias del Pará, Marañón, Bahía y Minas se han insurreccionado contra el déspota en defensa de sus derechos. [...] El día de la justicia no está lejos: los brasileros han de conocer al fin sus derechos y al tirano que se los usurpa: caerán sobre el malvado, desaparecerá del suelo de América, y nosotros tendremos la gloria de haber sido el instrumento para libertarla del último trono que ha pesado sobre ella." Etc., etc.; apud PALOMEQUE, Alberto, op. cit. p.488-490. O “jovem Rivera" é Bernabé, considerado instrumento de D. Frutos. 
${ }^{21}$ V. PALOMEQUE, Alberto. El General Rivera y La Campaña de Misiones (1828). Bs. As., Ed. Arturo E. López, 1914; CRUZ, Alcides. A incursão de Frutuoso Rivera às Missōes Brasileiras ou A Campanha de 1828. P. Alegre, Liv. Globo, 1914; BERAZA, Agustín. Rivera y la independencia de las Misiones. Montevideu, Ed. Banda Oriental, 1968; GARCIA, Flavio. Rivera en 1828. Separata do "Boletín Histórico" n. ${ }^{\circ}$ 60, do Estado Maior Geral do Exército. Montevidéu, 1963; idem, La Provincia de San Pedro ante la recuperación de las Misiones Orientales por Fructuoso Rivera. Separata do "Boletín Histórico" n. ${ }^{\text {os }} 54$ e 55 do Estado Maior Geral do Exército. Montevidéu, 1952; PORTO Aurélio. História das Missóes Orientais do Uruguai. 2. a ed. P. Alegre, Liv. Selbach, [ ], v.IV, cap.VII; ALENCASTRE, Álvaro. As Missões Orientais do Uruguai e o coronel Joaquim Antônio de Alencastre. in RIHGRGS, P. Alegre, $1933,1 .^{\circ}$ sem.; DOCCA, E. F. Souza. A Convenção Preliminar de Paz de 1828. São Paulo, Rossetti Ltda., 1929; idem, Limites entre o Brasil e o Uruguai. Rio de Janeiro Of. Gráf. Estab. Central de Intendência, 1939.

22 Agradecimentos ao Prof. Luís V. Anastasía, em Montevidéu, pela gentileza da informação e ac Prof. João-Francisco Ferreira, do Instituto de Letras da UFRGS, que prestativamente encaminhou a consulta. 